Document downloaded from:

http://hdl.handle.net/10251/117816

This paper must be cited as:

Miguel-Tortola, L.; Pallarés Rubio, L.; Miguel Sosa, P. (2018). Punching shear failure in three-pile caps: Influence of the shear span-depth ratio and secondary reinforcement. Engineering Structures. 155:127-142. https://doi.org/10.1016/j.engstruct.2017.10.077

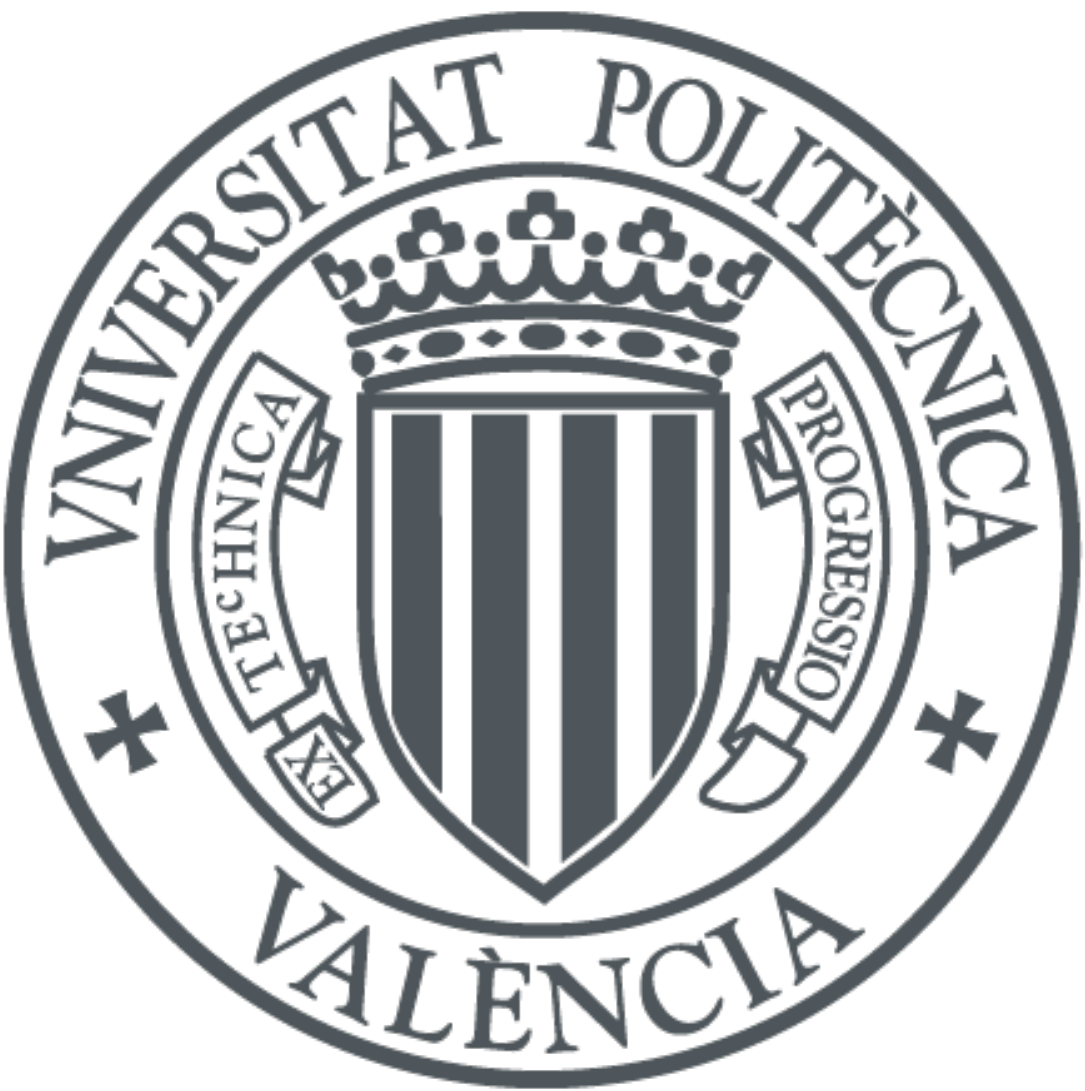

The final publication is available at

http://doi.org/10.1016/j.engstruct.2017.10.077

Copyright Elsevier

Additional Information 


\title{
Punching shear failure in three-pile caps: influence of the shear span-depth ratio and secondary reinforcement
}

\author{
Authors (Family name, Name) \\ Miguel-Tórtola, Lucía $^{\mathrm{a} *}$; Pallarés, Luis ${ }^{\mathrm{b}}$; Miguel, Pedro Francisco ${ }^{\mathrm{c}}$ \\ *Corresponding author: lumitor@upvnet.upv.es \\ ${ }^{a}$ Instituto de Ciencia y Tecnología del Hormigón (ICITECH), Universitat Politècnica de València, \\ Cami de Vera, s/n, 46022 Valencia, Spain \\ ${ }^{b}$ Instituto de Ciencia y Tecnología del Hormigón (ICITECH), Universitat Politècnica de València, \\ Cami de Vera, s/n, 46022 Valencia, Spain \\ ${ }^{c}$ Instituto de Ciencia y Tecnología del Hormigón (ICITECH), Universitat Politècnica de València, \\ Cami de Vera, s/n, 46022 Valencia, Spain
}

\begin{abstract}
The strut-and-tie model (STM) is currently established as the best approach for pile cap design. This model leads to efficient estimations of the main reinforcement placed in strips between piles. However, good practices and some international Concrete Design Standards recommend some secondary distributed reinforcement, and even vertical stirrups that are not considered by the STM. An experimental campaign with nine three-pile caps tested by a centered load is presented to show the influence of both secondary reinforcement and the shear spandepth ratio on pile cap strength.
\end{abstract}

The experimental results show a potential redistribution of internal forces in pile caps after yielding of main reinforcement, finally collapsed due to punching. Secondary reinforcement proves efficient to enhance pile cap strength since it takes part in complementary resistance mechanisms. As expected, the failure load increases with shear span-depth ratio reduction. The STM neither captures the effect of this ratio nor considers punching failure. Checking this failure mode is also required for pile caps.

The punching formulation of Eurocode 2 allows considering the influence of this ratio, but some interpretation is required whether one deals with pile caps, regarding the effective width of the shear enhancement factor and the definition of the basic control perimeter. A proper definition would prevent unsafe or very conservative results. Therefore, some recommendations for the verification of deep pile caps following the Eurocode 2 are presented. The contribution of vertical stirrups as punching reinforcement is also investigated. The proposed approach is applied to the existing experimental database of three- and four-pile caps to check formulation validity, and conservative predictions with low coefficient of variation are reached. 


\begin{tabular}{|c|c|c|c|}
\hline \multicolumn{4}{|c|}{ Notation } \\
\hline $\mathrm{A}_{1}$ & bearing area & $\mathrm{r}$ & thrust component normal to the tie \\
\hline$A_{\mathrm{sB}}$ & main bunched reinforcement & $\mathrm{t}$ & thrust component parallel to the tie \\
\hline $\mathrm{A}_{\mathrm{sH}}$ & horizontal secondary reinforcement & $\mathrm{T}_{\mathrm{sd}}$ & tensile force of vertical secondary ties \\
\hline $\mathrm{A}_{\mathrm{sV}}$ & vertical secondary reinforcement & $\mathrm{u}$ & basic control perimeter \\
\hline$a_{v}$ & $\begin{array}{l}\text { clear span; distance between column and } \\
\text { pile edges }\end{array}$ & $\mathrm{u}_{\mathrm{eff}}$ & effective control perimeter \\
\hline $\mathrm{c}$ & column diameter/side & $\mathrm{u}_{1}$ & basic control perimeter around the column \\
\hline $\mathrm{d}$ & effective depth & $\mathrm{u}_{2}$ & basic control perimeter around the piles \\
\hline$d_{g}$ & maximum size of aggregate & $\mathrm{u}_{\mathrm{z}}$ & vertical displacement at peak load \\
\hline e & distance between piles & $\mathrm{v}$ & $\begin{array}{l}\text { shear span; distance between column edge } \\
\text { and pile center }\end{array}$ \\
\hline$f_{b}$ & maximum bearing stress of concrete & $\mathrm{V}_{\mathrm{Rd}, \max }$ & $\begin{array}{l}\text { maximum punching shear resistance of } \\
\text { concrete: } 0.3 \cdot\left(1-f_{c} / 250\right) \cdot f_{c}\end{array}$ \\
\hline$f_{c}$ & cylinder compressive strength of concrete & $\mathrm{V}_{\mathrm{Rd}, \mathrm{c}}$ & punching shear resistance of concrete \\
\hline$f_{c t}$ & axial tensile strength of concrete & $\mathrm{V}_{\mathrm{Rd}, \mathrm{cs}}$ & $\begin{array}{l}\text { punching shear resistance when punching } \\
\text { reinforcement is provided }\end{array}$ \\
\hline$f_{u}$ & $\begin{array}{l}\text { ultimate strength of reinforcing steel in } \\
\text { tension }\end{array}$ & $\mathrm{w}_{\mathrm{eff}}$ & $\begin{array}{l}\text { effective width for the shear enhancement } \\
\text { factor }\end{array}$ \\
\hline$f_{y}$ & $\begin{array}{l}\text { yield strength of reinforcing steel in } \\
\text { tension }\end{array}$ & $\gamma_{\mathrm{c}}$ & $\begin{array}{l}\text { partial safety factor for concrete material } \\
\text { properties }\end{array}$ \\
\hline $\mathrm{h}$ & pile cap depth & $\gamma_{\mathrm{s}}$ & $\begin{array}{l}\text { partial safety factor for the material } \\
\text { properties of reinforcing steel }\end{array}$ \\
\hline $\mathrm{k}$ & size effect coefficient & $\theta_{\mathrm{d}}$ & strut-tie angle \\
\hline $\mathrm{n}$ & number of piles & $\rho_{1}$ & steel reinforcement ratio \\
\hline $\mathrm{P}_{\mathrm{d}}$ & design load & $\sigma_{\mathrm{s}}$ & $\begin{array}{l}\text { tensile stress of the punching } \\
\text { reinforcement }\end{array}$ \\
\hline $\mathrm{P}_{\mathrm{u}, \mathrm{b}}$ & maximum column bearing load & $\varphi$ & diameter of steel reinforcement \\
\hline $\mathrm{P}_{\mathrm{u}, \mathrm{e}}$ & experimental failure load & $\phi$ & pile diameter/side \\
\hline $\mathrm{P}_{\mathrm{y}, \mathrm{e}}$ & experimental yielding load & $\chi$-factor & coefficient for STM calibration \\
\hline $\mathrm{P}_{\mathrm{u}, \mathrm{STM}}$ & ultimate load predicted by the STM & $\chi_{\mathrm{d}}$ & $\chi$-factor for design according to EHE- 08 \\
\hline $\mathrm{P}_{\mathrm{u}, \mathrm{SV}}$ & ultimate load proposed by the authors & $\chi_{\mathrm{y}}$ & $\chi$-factor for yielding load \\
\hline$P_{u, V}$ & ultimate punching load by Eurocode 2 & $\chi_{u}$ & $\chi$-factor for ultimate load \\
\hline $\mathrm{P}_{\mathrm{u}, \mathrm{V} 0}$ & $\begin{array}{l}\text { ultimate punching load by Eurocode 2, not } \\
\text { considering shear enhancement }\end{array}$ & $\chi_{\mathrm{y}, \text { Souza }}$ & $\begin{array}{l}\chi \text {-factor for yielding load proposed by } \\
\text { Souza }\end{array}$ \\
\hline $\mathrm{P}_{\mathrm{u}, \text { Vred }}$ & $\begin{array}{l}\text { reduced ultimate punching load based on } \\
\text { Eurocode } 2\end{array}$ & $\chi_{\mathrm{u}, \text { Souza }}$ & $\begin{array}{l}\chi \text {-factor for ultimate load proposed by } \\
\text { Souza }\end{array}$ \\
\hline $\mathrm{P}_{\mathrm{u}, \text { Souza }}$ & $\begin{array}{l}\text { ultimate load predicted by the adaptable } \\
\text { STM of Souza }\end{array}$ & $\chi_{u, \text { Otsuki }}$ & $\begin{array}{l}\chi \text {-factor for ultimate load proposed by } \\
\text { Otsuki }\end{array}$ \\
\hline $\mathrm{P}_{\mathrm{y}, \mathrm{STM}}$ & yielding load predicted by the STM & $\xi$ & $\begin{array}{l}\text { Otsuki STM factor for taking e/d into } \\
\text { consideration }\end{array}$ \\
\hline $\mathrm{q}$ & vertical component of thrust & & \\
\hline
\end{tabular}




\section{Introduction}

In deep foundations, loads are transferred from columns to a group of piles through a large concrete member such as slender or deep pile caps. Deep pile caps are members whose distance from the axis of any pile to the edge of the column is more than twice the pile cap depth. Unlike slender pile caps, which are designed using a sectional approach like those used to design two-way slabs or footings supported on soil, deep pile caps are usually designed by strut-and-tie models.

Previous works by Blévot and Frémy [1], Clarke [2], Sabnis and Gogate [3], Adebar et al. [4] have provided the groundwork to design deep pile caps based on the STM. Further research has been conducted to gain a better understanding of failures of deep pile caps subjected to vertical loads. Suzuki et al. [5-8] conducted 94 tests on four-pile caps grouped as series to show the influence of reinforcement layout, the top face taper, cover of reinforcement and anchorage type. Deformation of upper and lower nodal zones has been researched by Delalibera and Giongo [9] on 14 two-pile caps tests, and Miguel et al. [10] did the same on 9 three-pile caps tests. The former reported the eccentricity of the reaction on piles. Gu et al. [11] studied the behavior of 4 four-pile caps with different layouts, including uniform grid, bunched reinforcement over adjacent piles or diagonal piles, and a combination of both. The concentration of the reinforcement on piles significantly increased pile cap strength, but improved ductility did not prove significant in their tests.

This experimental background presents the STM as an alternative approach to flexure methods that do not require complementary verifications beyond bearing load at column and pile sections. However, Bloodworth et al. [12], noticed that for reinforcement percentages higher than $0.3 \%$, the pile caps more likely fail in shear or punching than bending. They concluded that pile caps designed through truss analogy ignoring shear or punching failure became clearly unsafe. Souza et al. [13] proposed to limit the failure load obtained by STM with a shear formulation derived from deep beams. Jensen and Hoang [14] identified and analysed a number of collapse mechanisms (bending, shear and punching) based on the upper bound plasticity approach. More recently, Guo [15] determined the punching strength of pile caps with uniformly distributed reinforcement with a new limitation of the strut bearing load. 
Eurocode 2 [16] proposes both STM and sectional approaches as valid for determining the amount of bottom reinforcement regardless the slenderness of the pile cap. Practitioners find uncertainties up designing for punching strength whether the proposed critical section falls in the geometry of the piles. This scenario requires much interpretation, as pointed in the Designer's Guide to EN 1992-2 [17]. The shear enhancement due to support proximity is discussed, as it is neither consistent to consider it effective in the whole perimeter nor completely ignore its contribution.

\section{Objectives}

This work describes an experimental campaign on nine full-scale three-pile caps subjected to vertical load to provide results on the influence of the shear span-depth ratio on deep pile caps and the contribution of distributed horizontal reinforcement and vertical stirrups to strength.

Based on the experimental campaign carried out herein, in addition to the experimental tests found in the literature, Eurocode 2 [16] formulation for punching of deep pile caps is discussed and a simplified approach is proposed to account for punching strength in deep pile caps.

\section{Pile cap reinforcement arrangement by the STM}

Several specifications related to the pile cap reinforcement layout, found in Concrete Design Standards (Eurocode 2 [16], EHE-08 [18], BS 5400-4:1990 [19], NBR 6118:2014 [20]), are summarized in this section.

The main longitudinal bunched rebars between pile caps based on an STM design have been widely demonstrated to be the most efficient way to design deep pile caps subjected to centered vertical load [1,4]. Notwithstanding, distributed reinforcement should be located along the bottom side of pile caps to control soffit crack width, which is a recommendation in most standards despite the contribution made to the strength design being ignored. In this regard, Bloodworth [21] after analyzing the failure of four-pile caps under full width load, proposed a modification factor on the STM to take this secondary reinforcement into consideration. Table 1 summarizes the reinforcement distribution by distinguishing: the main bunched reinforcement $\left(\mathrm{A}_{\mathrm{sB}}\right)$, horizontal secondary reinforcement $\left(\mathrm{A}_{\mathrm{sH}}\right)$ and vertical secondary reinforcement $\left(\mathrm{A}_{\mathrm{sV}}\right)$. Eurocode $2[16]$ states that the reinforcement which derives 
from the STM should be concentrated between piles, and that distributed reinforcement is mandatory to achieve only minimum reinforcement. EHE-08 [18] also points out that $100 \%$ tension in ties should be carried by bunched reinforcement, and an extra $25 \%$ by distributed reinforcement. BS 5400-4:1990 [19] bunches $80 \%$ of the reinforcement designed through an STM in the strips that join pile heads, and the other $20 \%$ of reinforcement should be distributed uniformly throughout the pile cap. NBR 6118:2014 [20] recommends (at least) $85 \%$ of bunched reinforcement and an additional $20 \%$ as distributed reinforcement to control crack width.

Regarding vertical secondary reinforcement, EHE-08 [18] and NBR 6118:2014 [20] add stirrups along bunched reinforcement to prevent transverse tensile stress due to compression struts spreading. Vertical stirrups were firstly proposed by Leonhardt [22], who put forward suspension reinforcement if the pile caps distance was longer than three times the pile diameter in order to prevent any failure caused by thrust on "edge beams" between piles (a feasible conceptual STM is shown in Fig. 1). As pointed in [2], it is assumed that the vertical load is transferred to the piles by means of both direct struts to the piles and the distributed struts along the edges.

\section{Experimental research}

\subsection{Specimen design}

Tests were carried out on nine three-pile cap specimens with three different depths and three reinforcement layouts, including secondary horizontal and vertical reinforcement (Fig. 2). Table 2 summarizes the key features of these nine pile caps.

Pile spacing (e in Fig. 3) was set at $0.80 \mathrm{~m}$ for the piles with a $0.25-\mathrm{m}$ diameter ( $\phi$ in Fig. 3 ) to overcome the ratio of 3 times the pile diameter, which is the minimum distance to avoid the group interaction effect between piles from the geotechnical design viewpoint. According to the deep pile cap requirement, three different depths (h) are proposed: $0.25 \mathrm{~m}, 0.35 \mathrm{~m}$ and $0.45 \mathrm{~m}$. This leads to three groups of pile caps, respectively named A, B and C. Variations in depth may reveal the influence of the shear span-depth ratio on pile cap strength. 
According to the STM, bunched reinforcement $\left(\mathrm{A}_{\mathrm{sB}}\right)$ is designed to carry the same load $\left(\mathrm{P}_{\mathrm{d}}\right)$ of $500 \mathrm{kN}$ for all specimens. Following the STM presented in Fig. 4, Spanish standard EHE-08 [18] offers guidance on STM geometry about the top node elevation ( $0.85 \mathrm{~d}$ from the reinforcement axis) and the load point located on a perimeter of $0.25 \phi$ inside the column edge, taking as reference STM design. This leads to Eq. (1a), where $\chi_{\mathrm{d}}$ is 0.983 for the present series.

$$
\begin{aligned}
& A_{s B}=\frac{P_{d} \cdot e}{9 \cdot \chi_{d} \cdot f_{y} \cdot d} \\
& \chi_{d}=\frac{0.85 \cdot e / \sqrt{3}}{e / \sqrt{3}-0.25 c}
\end{aligned}
$$

Vertical secondary reinforcement $\left(\mathrm{A}_{\mathrm{sV}}\right)$ is considered by the authors to be a suspension reinforcement, as stated by Leonhardt [22], which carries the tensile force $\left(\mathrm{T}_{\mathrm{sd}}\right)$ derived from Eq. (2).

$$
T_{s d}=\frac{P_{d}}{1.5 \cdot n}, \quad \text { with } n \geq 3
$$

Horizontal secondary reinforcement $\left(\mathrm{A}_{\mathrm{sH}}\right)$ might be required to tie the horizontal component normal to the outside of the cap ( $\mathrm{r}$ in Fig. 1) since some thrust leading to the sides is formed.

An additional punching verification, following the Eurocode 2 [16] formulation, gives a better understanding of the likely structural response. Two different basic control perimeters (Fig. 4c) inside $2 \mathrm{~d}$ are considered. These can be tangent either to pile $\left(\mathrm{u}_{1}\right)$ or column $\left(\mathrm{u}_{2}\right)$, but in this case both lead to the same length of $2.1 \mathrm{~m}$. Otherwise the minimum should have been chosen.

A previous study, carried out by the authors, on the three pile caps tested by Blévot and Frémy [1] and Miguel et al. [10] failing in punching, revealed that the failure load was an intermediate value between that obtained without considering the contribution of the shear enhancement factor and considering it effective over the whole control perimeter. Thus, the boundaries of the expected punching strengths of the specimens are: type $\mathrm{A}(344.4 \mathrm{kN}-650.3 \mathrm{kN})$, type $\mathrm{B}(367.7 \mathrm{kN}-1041.2 \mathrm{kN})$, type C $(388.8 \mathrm{kN}-1468.2 \mathrm{kN})$. The stresses around the column perimeter under these loads have also been checked resulting for all cases less than $\mathrm{v}_{\mathrm{Rd}, \max }$. 
In this manner, based on the existing experimental observations and the design loads (STM or punching) this series of specimens is expected to capture different structural responses, the influence of the shear span-depth ratio and the secondary reinforcement in the pile cap strength.

\subsection{Material properties}

Pile caps are built mostly with normal-strength concrete because they are designed as massive elements. So high compressive stresses are not expected. Therefore, the designed strength of the concrete mixture is set at $25 \mathrm{MPa}$. The maximum aggregate size $\left(\mathrm{d}_{\mathrm{g}}\right)$ is $12 \mathrm{~mm}$ to prevent internal cavities over piles where the bunched reinforcements of two sides meet.

Table 3 presents the average compressive and tensile strengths and age of the concrete cylinders tested under the same temperature and humidity conditions as the pile caps. Compressive strength $\left(\mathrm{f}_{\mathrm{c}}\right)$ ranges from $21.28 \mathrm{MPa}$ to $28.53 \mathrm{MPa}$, and tensile strength $\left(\mathrm{f}_{\mathrm{ct}}\right)$ from $2.50 \mathrm{MPa}$ to $3.16 \mathrm{MPa}$. diameter were tested under tension (ISO 15630-1:2010 [23]) to determine an average value for yield $\left(f_{y}\right)$ and ultimate strength $\left(f_{u}\right)$. Table 4 offers the average mechanical properties of reinforcement.

\subsection{Test setup}

The specimens were designed to be loaded under a vertical centered load, provided by a $2000 \mathrm{kN}$ hydraulic jack. For simplicity sake, the column and piles were replaced with embedded steel plates while fabricating specimens. In order to ensure a perfectly vertical position of both the load and pile reactions, spherical supports were attached to bearing plates to act as a hinge. The three pile were also supported by ball bearings to release horizontal reactions, as shown in Fig. 5.b and Fig. 5.c. This test equivalent forces of the STM.

The whole test setup fits inside a steel frame which was anchored with four tension ties of $500 \mathrm{kN}$ to the strong floor of the ICITECH Laboratory (Fig. 5). Piles were supported by a cross steel base to spread the reaction over the slab. This base also acted as a pedestal and allowed the bottom side of the pile cap to be observed. 


\subsection{Instrumentation}

The specimen was loaded monotonically until failure at a constant deformation speed $(0.05$ $\mathrm{mm} / \mathrm{s}$ ). The total load applied to the pile cap was measured by a load cell (type C6A $1 \mathrm{MN}$, by HBM) located between the jack and the pile cap. Reactions were recorded by means of three load cells that were fitted under the pile-bearing system (type C6A 0.5MN, by HBM). The vertical displacements of the cap soffit were recorded with four displacement transducers LVDT: one in the middle under the pile cap and three over the piles.

A minimum of 32 and up to 56 strain gages were set on the rebars to record any strains along the main strips and secondary horizontal reinforcement versus load. Besides strain gauges, in order to record the horizontal average strain between piles and the vertical average strain on the sides, six LVDTs were connected to the pile cap sides by means of steel angular plates glued to the concrete surface. Location is presented in Fig. 3.

All the electronic measurements from the load cells, strain gages and LVDTs were automatically recorded during the test. Furthermore, seven photographic cameras and one HD-video camera were synchronized with data acquisition systems to plot the evolution of the cracks that appeared on the three sides and the underside. One photo per second was taken.

\section{Experimental results}

Table 5 lists the main experimental results, such as yielding load $\left(\mathrm{P}_{\mathrm{y}, \mathrm{e}}\right)$, failure load $\left(\mathrm{P}_{\mathrm{u}, \mathrm{e}}\right)$, vertical displacement at the pile cap soffit center $\left(\mathrm{u}_{\mathrm{z}}\right)$ and the failure mode deduced from different factors, like final cracking distribution, load-displacement response and yielding of reinforcement.

The load-displacement curves (Fig. 6) showed general brittle failure (close to 3-4 mm of the vertical displacement), except the ductile response of 3P-N-C3. The nine specimens reached the yielding point of the main reinforcement before the failure, and all except 3P-N-A1 exceed the STM design load. This reveals that the top node elevation of the STM adopted for design (Fig. 4.a,b) was safe for all the tests except 3P-N-A1, which did not reach that value. Nevertheless, the vertical displacement records after yielding do not show a noticeable stiffness variation of the pile cap. Only a 
clear change in the slope of the 3P-N-C3 load-displacement curve, due to yielding of the vertical reinforcement, is noticed.

\subsection{Failure load}

The main reinforcement of specimens 3P-N-A1, B1 and C1, whose only difference is the v/d ratio, was designed to ensure the same load level $(500 \mathrm{kN})$ according to a basic strut-and-tie model. However, different failure loads and responses were observed, confirming the influence of the shear span-depth ratio and the secondary reinforcement in pile cap strength (Fig. 7). Deeper pile caps, with a lower shear span-depth ratio $(\mathrm{v} / \mathrm{d}=0.84)$, showed higher ultimate loads than the slender ones $(\mathrm{v} / \mathrm{d}=$ 1.68).

The effects of horizontal and vertical secondary reinforcements on the resistance of pile caps also vary depending on the depth of the element. For the type A specimens, adding horizontal and vertical reinforcements increased failure loads ( $20 \%$ and $29 \%$, respectively). Adding horizontal secondary reinforcement was effective for the type B specimens (load increase of 7.5\%), but stirrups did not significantly increase the load capacity between B2 and B3 (8\% related to B1 and only $0.5 \%$ related to B2). On the contrary, adding only horizontal secondary reinforcement in type $\mathrm{C}$ specimens did not lead to a greater load capacity. In this case, vertical secondary reinforcement had a significant impact on strength (a 14\% increase related to $\mathrm{C} 1$ and $\mathrm{C} 2$ ), and especially on the ductility of the element.

\subsection{Reinforcement yielding}

Based on the recordings of the strain gages on main bunched reinforcement (point value) and the LVDTs on the axes between piles (mean value), the yielding load $\left(\mathrm{P}_{\mathrm{y}, \mathrm{e}}\right)$ was the minimum load at which larger strain measurements were recorded than the yielding strain.

Table 5 also shows the effects of secondary reinforcement and pile cap depth on behavior after yielding up to the failure of specimens in the ratio $\mathrm{P}_{\mathrm{u}, \mathrm{e}} / \mathrm{P}_{\mathrm{y}, \mathrm{e}}$.

Both specimens 3P-N-A1 and B1 showed close yielding and failure loads (13\% increase), but a large increment (around 30\%) when distributed horizontal rebars and vertical stirrups were placed. The type $\mathrm{C}$ specimens did not vary the ultimate load percentage in relation to yielding load, and were maximum and around $30 \%$ in all cases. 


\subsection{Cracking pattern}

Plotting the cracking pattern evolution versus load revealed the main tension stress field stages. Specimen 3P-N-A3, as illustrated in Fig. 8, shows the typical types of cracks identified in all specimens. First, early bending cracks (a) appeared between piles, and larger strains started to be recorded for the main ties. These cracks were vertical on the side faces and propagated toward the pile cap soffit center. Close to the yielding threshold, some diagonal shear cracks (b) developed close to the piles and future arched cracks started. This indicated a potential punching failure surface. When the failure load took place, fully developed arched cracks were visible on the three faces (c). Then the tail of shear cracks (d) suddenly appeared and extended across the pile head.

The main differences in cracking patterns observed between specimens (Fig. 9, Fig. 10 and Fig. 11) were soffit crack width and the slope of the lateral arched cracks. The effect of horizontal secondary reinforcement on reducing the crack width of the underside was proved regardless of pile cap depth. This improvement was clearly seen when comparing the photos of the underside of 3P-NB1 and B2 after the peak load. Thicker radial cracks ran from the piles to the center (Fig. 10.a) and were crossed by secondary reinforcement (Fig. 10.b).

The slope of the lateral arched cracks rose with pile cap depth, so $\mathrm{C} 1$ and $\mathrm{C} 2$ were unable to develop full arches on the three sides. Adding vertical secondary reinforcement to specimen C3 helped to cross these cracks (Fig. 11), which caused an increase of failure load. Slender pile caps (types A and B) showed well-defined arches on the three sides. In these cases, stirrups did not cross the arched cracks, but modified the failure surface of specimen A3 by increasing punching capacity. Negligible differences for cracking pattern and failure load were found between B2 and B3.

\subsection{Failure mode}

Failure modes are judged by taking into account all the previous comments. The lateral arched cracks revealed a complex punching failure surface (Fig. 12.a), similarly to those proposed by Clarke [2] or Jensen [14]. The punching failure occurred in all 9 cases after yielding of the main reinforcement. Despite that, 3P-N-A1, A2, A3, B1, B2, B3, C1 and C2 showed a brittle loaddisplacement response. The absence of a plateau in the load-displacement curves after the yielding 
point could be explained by a redistribution of concrete stresses. In this manner, the pile caps resist further load without an increase of the tensile stress in the reinforcement. This stress redistribution requires accepting some tensile strength of concrete, that finally leads to the punching failure of the pile cap.

The contribution of vertical stirrups to the punching strength of 3P-N-C3 lead to a ductile failure, based on load-displacement curves and cracking pattern.

\section{Discussion}

\subsection{Shear span-depth ratio}

As mentioned in the results, there is a clear trend between the ultimate load and the shear spandepth ratio. The deeper specimens reached higher failure loads, up to 1.6 times the design load.

The influence of the shear span-depth ratio on the shear strength of beams was first demonstrated by Kani [24] for beams without shear reinforcement. Dealing with pile caps, Souza et al. [13] also reported this effect in the ultimate strength and set the limits for the sectional design methods to $\mathrm{v} / \mathrm{d}>$ 1.5 , being the STM more suitable only for ratios below 1.5 .

\subsection{Secondary horizontal and vertical reinforcement}

The addition of secondary and vertical reinforcement increased the percentage of load resisted after yielding of the bunched reinforcement. These results indicate that the secondary reinforcement plays an important role in the redistribution capacity of the concrete stresses and has a favorable effect on punching resistance. This favorable effect is clearly shown in the test of the specimen 3P-N-C3, whose vertical stirrups yielded before reaching the failure load. A3 and B3 showed flatter arched cracks and the stirrups should have been closer to the piles to provide the expected enhancement.

Regarding the cracking pattern, the addition of secondary horizontal reinforcement reduced the crack width. In types A and B, this led to clearly meant less damage to the direct struts, which became an increase of the ultimate load. On the contrary, as the main cracks for type $\mathrm{C}$ began in the middle of the faces, the main struts were not crossed by these cracks, and almost the same ultimate load was recorded for specimens $\mathrm{C} 1$ and $\mathrm{C} 2$. 


\subsection{Comparison with STM predictions}

The main reinforcement is derived from the STM assuming a certain top node elevation in design,

268

269

270 as indicated in Eqs. (1a) and (1b). For this reason, it is considered of interest to compare yielding and failure loads with the design load. Eq. (3) enables the computation of the ultimate load $\mathrm{P}_{\mathrm{u}, \mathrm{STM}}$ and the yielding load $\mathrm{P}_{\mathrm{y}, \mathrm{STM}}$ predicted by the STM using the appropriate $\chi$-factor $\left(\chi_{\mathrm{y}}\right.$ for yielding and $\chi_{\mathrm{u}}$ for ultimate) for three-pile caps. Since each specimen reached different peak loads, $\chi$-factor was selected as a variable to experimentally determine its value upon yielding and peak load (Table 6). This coefficient simultaneously takes into account the top node elevation (as a multiple of the effective depth (d)), and the effect of the strain-hardening of reinforcing steel $\left(\chi=\chi_{\mathrm{y}}\right.$ for yielding load and $\chi=\chi_{\mathrm{u}}$ for ultimate load). Table 6 includes $\chi_{\mathrm{d}}=0.983$ from Eq. $(1 \mathrm{~b})$ as a reference to compare the experimental and design values of the $\chi$-factors.

$$
P_{S T M}=\chi \cdot \frac{9 \cdot A_{S B} \cdot f_{y} \cdot d}{e}
$$

A similar four-pile caps approach was proposed by Souza et al. [13]. These authors' simple analytical model predicts the failure mode (bending or shear) and cracking, yielding and peak load. The flexural strength of the pile cap is also based on the STM, where $\chi_{\mathrm{y}}$ and $\chi_{\mathrm{u}}$ are coefficients of calibration to reach the sample's lowest coefficient of variation. Shear failure is assumed to be related to the splitting of struts and, as proposed by Siao [25], might be estimated as the sum of the shear capacities of two intersecting beams. The $\chi$-factors are constant and become $\chi_{\mathrm{y}, \text { Souza }}=1.88$ and $\chi_{\mathrm{u} \text {,Souza }}=$ 2.05 after calibration. The relationship that connects these two coefficients is based on the strain hardening branch of reinforcement after the yield point, as the authors explain.

Otsuki and Suziki [26] reported the influence of the shear span-depth ratio on the stress concentration in the vicinity of the column edge, and how the inclination of struts is affected. They proposed a formula that includes this parameter. This formula is rewritten in terms of the $\chi$-factor for the three-pile caps in Eq. (4): 


$$
\chi_{u, \text { otsuki }}=\frac{e / \sqrt{3}}{e / \sqrt{3}-\xi \cdot c / 2}, \quad \text { where } \xi=\left\{\begin{array}{lr}
0.75 & e / d \leq 1.5 \\
0.75+0.25 \cdot(e / d-1.5) & 1.5<e / d \leq 2.5 \\
1 & e / d>2.5
\end{array}\right.
$$

With the tests presented in the current campaign, it was observed (Fig. 13.a.1) that the yield point estimations according to reference STM design in Fig. 4 were unsafe for type A specimens (v/d = $\left.1.68, \theta_{\mathrm{d}}=23^{\circ}\right)$. In fact, Blévot and Frémy [1] recommended an angle of the strut-tie that lies between $35^{\circ}$ and $45^{\circ}$. According to Blévot and Frémy [1], the failure modes in specimens with angles less than $35^{\circ}$ become more complex and difficult to analyze. However in the current campaign, the STM strength estimations were quite conservative (Fig. 13.a.2). Only the failure load prediction for the A1 specimen was non-conservative. Indeed the limitations in the $\mathrm{v} / \mathrm{d}$ ratio were closely related to the limits in the strut-tie angle. Both parameters are compared in Table 6.

Fig. 13 shows that STMs cannot explain the failure load increase when the shear span-depth ratio decreases, which commonly occurs in shear failure. When $\chi_{\mathrm{u}, \text { Otsuki }}$ is considered, only the deeper pile caps $(\mathrm{v} / \mathrm{d}$ ratio $<1)$ became a conservative estimation (Fig. 13.b).

Both yielding and failure predictions considering $\chi_{\mathrm{y}, \text { Souza }}$ and $\chi_{\mathrm{u}, \text { Souza }}$, resulted in non-conservative predictions (Fig. 13.c.1 and Fig. 13.c.2). However, Fig. 13.c.3 shows that the adaptable STM proposed by Souza [13] well describes the shear span-depth ratio by adding a complementary shear formulation. Unfortunately, the adaptable STM became unsafe for three-pile caps since it was developed for fourpile caps. Different calibration coefficients must be proposed and shear formulation also needs some adjustments.

\subsection{Limitation of punching failure}

\subsubsection{Bearing stress limits}

In order to restrain fragile failure modes with the STM design, Adebar et al. [27,28] proposed a maximum bound of bearing stresses in nodal zones (column and piles) to avoid transverse splitting in struts. A more recent work by Guo [20] states that the loss of the punching pile cap strength is a strut failure. Based on STM and nonlinear finite element analysis, a different bearing stress limitation is proposed, valid only for pile caps with uniform grid reinforcement. Both authors, in view of the 
complexity of defining a three-dimensional geometry of the struts and nodes suggest a simpler bearing stress evaluation.

Similar to the above approaches, Eq. 5 is available in Eurocode 2 [16] to limit stresses in the struts with transverse tension. Following the usual procedure in pile caps, the compression is limited in the bearing areas, either column or pile sections.

$$
f_{b} \leq 0.6 \cdot\left(1-f_{c} / 250\right) \cdot f_{c}
$$

For the design load given by the STM $(500 \mathrm{kN})$, the stresses located below the column were lower than bearing stress limit $\left(\mathrm{f}_{\mathrm{b}}\right)$. So, no fragile failure would appear. When comparing the peak load from the tests with the maximum bearing load over the column $\left(A_{1} \cdot f_{b}\right)$, the estimations for specimens type A (Table 7 and Fig. 14.a) became non-conservative and did not capture the shear span-depth effect on pile cap strength.

\subsubsection{Proposed punching formulation}

An approach to compute the fragile failure of pile caps, based on punching failure similarities, is proposed herein. The existing design provisions for punching shear were not specifically developed for deep members or applied loads in the vicinity of the columns. In these cases, it was impossible to completely develop the failure surface to form a theoretical conical frustum, so the empirical formulation proposed in Standards may not be accurate. Section 10.4.5 of the fib Bulletin-12 [29] states that the geometry of the failure surface plays an important role in punching strength, especially when the failure surface is forced into a shape that differs from that which considers normal punching resistance. Regan [30] proved this fact with a series of tests done on slabs by varying geometry (square or round) and the distance between column and piles. Regan later proposed [31] a change in the basic control perimeter proposed by Model Code 90 [32], from $2 \mathrm{~d}$ to $\mathrm{d} / 4$, in order to deal with highly concentrated loads.

Two factors can describe the properties of this singular failure surface based on the empirical punching formulation of Eurocode 2 [16]: the basic control perimeter $(\mathrm{u})$ and the shear enhancement factor $\left(2 \mathrm{~d} / \mathrm{a}_{\mathrm{v}}\right)$. Eurocode $2[16]$ proposes the shear enhancement factor to check the critical perimeters inside $2 \mathrm{~d}$. In deep pile caps some degree of enhancement was previously proved effective by Clarke 

be considered. The complete punching formulation of Eurocode 2 [16], considering the shear enhancement factor is presented in Eqs. (6a) to (7b):

$$
\begin{gathered}
V_{R d, c}=\left[\frac{0.18}{\gamma_{c}} \cdot\left(f_{c}\right)^{1 / 3} \cdot\left(100 \cdot \rho_{l}\right)^{1 / 3} \cdot k \cdot \frac{2 d}{a_{v}}\right] \cdot u \cdot d \\
k=1+\sqrt{\frac{200}{d}} \leq 2
\end{gathered}
$$

If punching reinforcement is provided, then punching strength is computed as follows:

$$
\begin{gathered}
V_{R d, c s}=0.75 \cdot V_{R d, c}+1.5 \cdot A_{s V} \cdot \sigma_{s} \\
\sigma_{s}=250+0.25 \cdot d \leq \frac{f_{y}}{\gamma_{s}}
\end{gathered}
$$

By following this formulation, basic control perimeter and shear enhancement factor $\left(2 \mathrm{~d} / \mathrm{a}_{\mathrm{v}}\right)$ can be reformulated to the particular case of deep pile caps. In order to compare the failure loads from the experiments with the design formulae, the real strength of materials is used, and $\gamma_{\mathrm{c}}, \gamma_{\mathrm{s}}$ are set as 1.00 . Punching failure is evaluated for each pile, and the ultimate punching load $\left(\mathrm{P}_{\mathrm{u}, \mathrm{V}}\right)$ to be compared with the experimental ultimate load $\left(\mathrm{P}_{\mathrm{u}, \mathrm{e}}\right)$ is n-times $\mathrm{V}_{\mathrm{Rd}, \mathrm{c}}$ or $\mathrm{V}_{\mathrm{Rd}, \mathrm{cs}}$.

\section{Basic control perimeter ( $\mathrm{u}$ ) for deep pile caps}

Far from being a conical surface, the observed punching surface (Fig. 12.a) is similar to the intersection of three domes between piles. A minimum-length line appears and connects both the column and pile edges. The most coherent simplified control surface is defined by intersecting the vertical planes located in the middle of this line (Fig. 12.b).

\section{$\underline{\text { Shear enhancement factor }\left(2 \mathrm{~d} / \mathrm{a}_{\mathrm{v}}\right) \text { for deep pile caps }}$}

Non-conservative load capacity estimations are obtained by applying the shear enhancement factor to the whole control section, but very safe predictions are reached when is not considered (Table 7). Applying the enhancement factor only to a reduced part of this basic control section seems more proper. This has already been discussed in 14 half-scale four-pile caps tested by Clarke [2]. Clarke suggested applying the shear enhancement factor only to the sections whose reinforcement is fully anchored by crossing over piles. This proposal was adopted later by the BS 5400-4:1990 [19]. Cao et 
al. [33] studied which cap width is the shear enhancement effective at, provided that there is

362

363

364

365

366

367

368

369

370

371

372 discrepancy between BS 5400-4:1990 [19] and BS 8110-1:1997 [34]. The latter indicates a width that is threefold the pile diameter centered on each pile head, instead of just one diameter. The comparison made with 17 four-pile caps subjected to full-width loading showed that both formulations resulted in conservative predictions.

For the current three-pile cap series, subjected to a centered load and a main reinforcement placed on strips over piles, applying the shear enhancement factor $\left(2 \mathrm{~d} / \mathrm{a}_{\mathrm{v}}\right)$ to an effective width that equals the column-pile average diameter $\mathrm{w}_{\mathrm{eff}}=(\mathrm{c}+\phi) / 2$ seems appropriate (diameter of the equivalent circular area should be considered for a square column or pile). Thus the effective control perimeter to be used in Eq. (6a), to get $P_{u, V r e d}$, may be expressed by $u_{\text {eff }}=u+\left(2 d / a_{v}-1\right) \cdot w_{\text {eff. }}$ This leads to an accurate prediction (plotted in Fig. 14 c). A comparison of predicted loads versus experimental failure load is summarized in Table 7.

\subsection{Formulation proposed for verification of pile caps}

The STM is based on the lower bound theorem of plastic theory and therefore leads to conservative predictions, since all materials failure are checked. Unfortunately, the concrete verification cannot be reduced to a simple stress check. For this reason, the traditional STMs proposals $[1,18,28]$ have defined a moderate top node elevation to avoid concrete failures.

The safe predictions of the STM do not provide information on the internal redistribution of stresses after main reinforcement yields. To accurately predict the failure load of pile caps $\left(\mathrm{P}_{\mathrm{u}, \mathrm{SV}}\right)$, an extended formulation (Eq. (8)) should be used which, on the one hand, considers this internal redistribution of stresses, and on the other hand includes a punching verification. The STM proposal by Otsuki [26] (Eqs. 3 and 4) allows considering this redistribution by a variable top node elevation, and the formulation presented in section 6.4.2 enables the punching verification.

$$
\mathrm{P}_{\mathrm{u}, \mathrm{SV}}=\min \left\{\begin{array}{l}
\mathrm{P}_{\mathrm{u}, \mathrm{STM}(\chi \mathrm{u}, \mathrm{Otsuki})} \\
\mathrm{P}_{\mathrm{u}, \mathrm{Vred}}
\end{array}\right.
$$

In order to check the validity of the proposed formulation for the general deep pile caps case, it is applied to the experimental database of the three- and four-pile cap tests carried out by Blévot and 
Frémy [1], Clarke [2], Suzuki et. al [5-8] and Miguel et. al [10] (refer to Table 1Table 8 and Table 9). 39 three-pile caps and 111 four-pile caps form the experimental database. Plain concrete specimens (without reinforcement), those with mild steel rebars or an effective depth less than $200 \mathrm{~mm}$ were excluded from this validation process. In order to fulfill Eurocode 2 [16] prescriptions, safety coefficients $\gamma_{c}, \gamma_{s}(1.5,1.15)$ should be considered, and then $99.5 \%$ of the specimens should meet the proposed formulation.

As shown in Fig. 15, results for three-pile caps reveal that all the failure loads predicted by the design proposal become conservative, the shear span-depth ratio is well-described and the COV lowers from 0.29 (STM) to 0.16 for the combined formulation in three-pile caps. Only one specimen of four-pile caps $(11,2 \mathrm{a})$ is non-conservative $\left(\mathrm{P}_{\mathrm{u}, \mathrm{e}} / \mathrm{P}_{\mathrm{u}, \mathrm{SV}}=0.94\right)$. Yet as shown in Fig. 16, the proposed formulation for four-pile caps is safer than the STM, and the COV also lowers from 0.25 (STM) to 0.18 for the proposed formulation.

\section{Conclusion}

A series of nine experiments on three-pile caps, with variations in shear span-depth ratio and reinforcement layout, was carried out to determine differences in their structural response and the effectiveness of shear reinforcement. Results are useful to improve failure load formulations to achieve more accurate predictions.

The tests revealed ultimate loads increase with a lower shear span-depth ratio (up to $80 \%$ for the type 1 specimens - bunched reinforcement only). It was not possible to analyze the influence of the reinforcement layout separately from this shear span-depth ratio. In general however, secondary reinforcement clearly contributed to raise peak loads (29\% type A, $8 \%$ type B and $14 \%$ type C) and to increase strength after yielding (from 13\% to 30\%, type A and B). The same depth specimens yielded at a similar load, and the evolution to higher ultimate loads was explained by the horizontal and vertical secondary reinforcement contributions, which enabled stress redistribution to reach higher failure loads. In fact, the vertical stirrups of specimen 3P-N-C3 helped avoid the brittle failure recorded in 3P-N-C2 by crossing the arched cracks of the sides. 
displacement curves of all the specimens (excluding C3) revealed a sudden failure, which is typical of punching. The STM results proved accurate for yielding load predictions, but captured neither the shear span-depth ratio effect, nor any fragile failures that could have occurred before yielding.

A punching verification is also required besides the design of the main reinforcement based on STM. The punching formulation of Eurocode 2 [16] needs some interpretation to be applied to deep pile caps $(\mathrm{v} / \mathrm{d} \leq 2)$. Not considering the shear enhancement factor leads to very conservative predictions of the punching load, while applying it to the whole surface is unsafe. A simple modification of the basic control perimeter and the effective width of shear enhancement factor, well describe the distinctive features of the punching surface and can be easily applied to the general case. The basic control perimeter is restricted by the distance between column and piles. The shear enhancement factor can be considered effective in a width equal to the column-pile average diameter. Following the general prescriptions of Eurocode 2 [16], vertical stirrups can be considered as punching reinforcement with conservative results.

The proposed approach has been extended to the existing experimental database of three- and four-pile caps to check the validity of the formulation, reaching a low $\operatorname{COV}(0.15-0.18)$. This verification proposal enables more rational design and would save costs. Even so, further research on more complex strut-and-tie models and analytical punching formulations could lead to even better understanding of the structural response of pile caps. Besides, it would be interesting to extend the experimental research on pile caps subjected to eccentric loads to prove the validity of the proposed formulation.

\section{Acknowledgments}

The authors would like to acknowledge the funding received from the Spanish Ministry of Economy and Competitiveness for basic non oriented research projects (BIA2012-32300), which also included a PhD fellowship (BES-2013-063409). 


\section{References}

[1] Blevot J, Frêmy R. Semelles sur pieux. Ann l'Institut Tech Du Bâtiment Des Trav Publics 1967;20:223-95.

[2] Clarke JL. Behaviour and design of pile caps with four pile caps. Cem Concr Assoc 1973.

[3] Gogate AB, Sabnis GM. Design of thick pile caps. ACI J 1980;77:18-22.

[4] Adebar P, Kuchma D, Collins MP. Strut-and-tie models for the design of pile caps: an experimental study. ACI Struct J 1990;87:81-92.

[5] Suzuki K, Otsuki K, Tsubata T. Influence of bar arrangement on ultimate strength of four-pile caps. Trans Japan Concr Inst 1998;20:195-202.

[6] Suzuki K, Otsuki K. Experimental study on corner shear failure of pile caps. Trans Japan Concr Inst 2002;23:30310 .

[7] Suzuki K, Otsuki K, Tsuchiya T. Influence of Edge Distance on Failure Mechanisms of Pile Caps. Trans Japan Concr Inst 2000;22:361-8.

[8] Suzuki K, Otsuki K, Tsubata T. Experimental Study on Four Pile Caps with Taper. Trans Japan Concr Inst 1999;21:327-34.

[9] Delalibera RG, Giongo JS. Deformations in the strut of two pile caps. Rev IBRACON Estruturas E Mater 2008;1:121-57. doi:10.1590/S1983-41952008000200002.

[10] Miguel MG, Takeya T, Giongo JS. Structural behaviour of three-pile caps subjected to axial compressive loading. Mater Struct 2008;41:85-98. doi:10.1617/s11527-007-9221-5.

[11] Gu Q, Sun CF, Peng SM. Experimental Study on Deep Four-Pile Caps with Different Reinforcement Layouts Based on 3D Strut-and-Tie Analogy. Key Eng Mater 2009;400-402:917-22. doi:10.4028.

[12] Bloodworth AG, Jackson PA, Lee MMK. Strength of reinforced concrete pile caps. Proc Inst Civ Eng - Struct Build 2003;156:347-58.

[13] Souza R, Kuchma D, Park J, Bittencourt T. Adaptable Strut and Tie Model for Design and Verfication of four pile caps. ACI Struct J 2009;106:142-50.

[14] Jensen UG, Hoang LC. Collapse mechanisms and strength prediction of reinforced concrete pile caps. Eng Struct 2012;35:203-14. doi:10.1016/j.engstruct.2011.11.006.

[15] Guo H. Evaluation of column load for generally uniform grid-reinforced pile cap failing in punching. ACI Struct J 2015;112. doi:10.14359/51687420.

[16] CEN. Eurocode 2: Design of concrete structures - Part 1-1: General rules and rules for buildings; Spanish version UNE-EN-1992-1-1:2004. 2013.

[17] Hendy CR, Smith DA. Designers' Guide to EN 1992-2. London: Thomas Telford; 2007.

[18] Comisión Permanente del Hormigón. Instrucción de Hormigón Estructural EHE-2008. Madrid: Ministerio de Fomento; 2008.

[19] BS 5400-4: 1990 Steel, concrete and composite bridges — Part 4: Code of practice for design of concrete bridges. British Standard Institution; 1990.

[20] NBR 6118:2014 Design of concrete structures - Procedure (In Portuguese). Rio de Janeiro City, Brazil: Brazilian Association of Technical Standards; 2014.

[21] Bloodworth AG, Cao J, Xu M. Numerical Modeling of Shear Behavior of Reinforced Concrete Pile Caps. J Struct Eng 2012;138:708-17. doi:10.1061/(ASCE)ST.1943-541X.0000499.

[22] Leonhardt F. Vorlesungen über Massivbau. Berlin/Heidelberg: Springer-Verlag; 1974.

[23] CEN. UNE-EN ISO 15630-1 Steel for the reinforcement and prestressing of concrete. Test methods. Part 1: Reinforcing bars, wire rod and wire. 2010.

[24] Kani GNJ. Basic facts concerning shear failure. ACI J Proc 1966;63:675-92.

[25] Siao W Bin. Strut-and-Tie model for shear behavior in deep beams and pile caps failing in diagonal splitting. ACI Struct J 1993;90:356-63.

[26] Otsuki K, Suzuki K. Experimental Study on Bending Ultimate Strength of Four Pile Caps. Trans Japan Concr Inst 1996:93-102. 

41.

489 [28] Adebar P, Zhou Z. Design of deep pile caps by strut-and-tie models. ACI Struct J 1996;93:437-48.

490 [29] FIB. Punching of structural concrete slabs. fib Bulletin 12. Lausanne, Switzerland: 2001.

491 [30] Regan PE. The dependence of punching resistance upon the geometry of the failure surface. Mag Concr Res 1984;36:3-8.

493 [31] Regan PE. Punching of slabs under highly concentrated loads. Proc Inst Civ Eng - Struct Build 2004;157:165-71.

494 [32] CEB-FIP. Model Code 1990. London: Thomas Telford; 1993.

495 [33] Cao J, Bloodworth AG. Shear behaviour of reinforced concrete pile caps under full-width wall loading. Proc Inst Civ Eng - Struct Build 2012;165:165-77.

[34] BS 8110-1:1997 Structural use of Concrete. Part 1: Code of practice for design and construction. British Standard Institution; 1997. 
502 Table 1 Recommended reinforcement distribution for pile caps

\begin{tabular}{lccc}
\hline Concrete Design & $\begin{array}{c}\mathrm{A}_{\mathrm{sB}} \\
(\%)\end{array}$ & $\begin{array}{l}\mathrm{A}_{\mathrm{sH}} \\
(\%)\end{array}$ & $\begin{array}{c}\mathrm{A}_{\mathrm{sV}} \\
(\%)\end{array}$ \\
\hline Standard & 100 & min reinf. & - \\
\hline Eurocode 2 [16] & 80 & 20 & - \\
BS 5400-4:1990 [19] & 100 & 25 & $\mathrm{P}_{\mathrm{d}} /(1.5 \mathrm{n})$ \\
EHE-08 [18] & $>85$ & 20 & If $\mathrm{A}_{\mathrm{sH}}>25 \%$ or \\
NBR 6118:2014 [20] & & & e $3 \phi$ \\
\hline
\end{tabular}

$\mathrm{A}_{\mathrm{sB}}$ : main bunched reinforcement; $\mathrm{A}_{\mathrm{sH}}$ : horizontal secondary reinforcement;

$\mathrm{A}_{\mathrm{sV}}$ : vertical secondary reinforcement (in stirrups);

$\mathrm{P}_{\mathrm{d}}$ : design load; $\mathrm{n}$ : number of piles; e: pile spacing; $\phi$ : pile diameter

504 Table 2 Key features of pile cap specimens

\begin{tabular}{cccccccc}
\hline Specimen & $\begin{array}{c}\mathrm{h} / \mathrm{d} \\
(\mathrm{m})\end{array}$ & $\begin{array}{c}\mathrm{e} \\
(\mathrm{m})\end{array}$ & $\begin{array}{c}\phi \\
(\mathrm{m})\end{array}$ & $\begin{array}{c}\mathrm{c} \\
(\mathrm{m})\end{array}$ & $\begin{array}{c}\mathrm{A}_{\mathrm{sB}} \\
\left(\mathrm{cm}^{2}\right)\end{array}$ & $\begin{array}{c}\mathrm{A}_{\mathrm{sH}} \\
\left(\mathrm{cm}^{2}\right)\end{array}$ & $\begin{array}{c}\mathrm{A}_{\mathrm{sV}} \\
\left(\mathrm{cm}^{2}\right)\end{array}$ \\
\hline 3P-N-A1 & $0.25 / 0.20$ & 0.80 & 0.25 & 0.25 & $4.52(3 \times 4 \varphi 12)$ & - & - \\
3P-N-A2 & $0.25 / 0.20$ & 0.80 & 0.25 & 0.25 & $4.52(3 \times 4 \varphi 12)$ & $2.36(3 \times 3 \varphi 10)$ & - \\
3P-N-A3 & $0.25 / 0.20$ & 0.80 & 0.25 & 0.25 & $4.52(3 \times 4 \varphi 12)$ & $2.36(3 \times 3 \varphi 10)$ & $3.02(3 \times 3 \mathrm{~s} \varphi 8)$ \\
\hline 3P-N-B1 & $0.35 / 0.30$ & 0.80 & 0.25 & 0.25 & $3.05(3 \times 2 \varphi 12+1 \varphi 10)$ & - & - \\
3P-N-B2 & $0.35 / 0.30$ & 0.80 & 0.25 & 0.25 & $3.05(3 \times 2 \varphi 12+1 \varphi 10)$ & $1.51(3 \times 3 \varphi 8)$ & - \\
3P-N-B3 & $0.35 / 0.30$ & 0.80 & 0.25 & 0.25 & $3.05(3 \times 2 \varphi 12+1 \varphi 10)$ & $1.51(3 \times 3 \varphi 8)$ & $3.02(3 \times 3 \mathrm{~s} \varphi 8)$ \\
\hline 3P-N-C1 & $0.45 / 0.40$ & 0.80 & 0.25 & 0.25 & $2.36(3 \times 3 \varphi 10)$ & - & - \\
3P-N-C2 & $0.45 / 0.40$ & 0.80 & 0.25 & 0.25 & $2.36(3 \times 3 \varphi 10)$ & $1.51(3 \times 3 \varphi 8)$ & - \\
3P-N-C3 & $0.45 / 0.40$ & 0.80 & 0.25 & 0.25 & $2.36(3 \times 3 \varphi 10)$ & $1.51(3 \times 3 \varphi 8)$ & $3.02(3 \times 3 \mathrm{~s} \varphi 8)$ \\
\hline
\end{tabular}

$\mathrm{h}$ : height of pile cap; d: effective depth; e: pile spacing between axis; $\phi$ : pile diameter; c: column diameter;

$\mathrm{A}_{\mathrm{sB}}$ : main bunched reinforcement; $\mathrm{A}_{\mathrm{sH}}$ : horizontal secondary reinforcement;

$\mathrm{A}_{\mathrm{sV}}$ : vertical secondary reinforcement (in stirrups); $\varphi$ : diameter of reinforcement; 
508 Table 3 Mechanical properties of concrete

\begin{tabular}{cccc}
\hline Specimen & $\begin{array}{c}\text { Age } \\
(\text { days })\end{array}$ & $\begin{array}{c}\mathrm{f}_{\mathrm{c}} \\
(\mathrm{MPa})\end{array}$ & $\begin{array}{c}\mathrm{f}_{\mathrm{ct}} \\
(\mathrm{MPa})\end{array}$ \\
\hline 3P-N-A1 & 24 & 23.31 & 2.53 \\
3P-N-A2 & 32 & 22,85 & 2.70 \\
3P-N-A3 & 36 & 23.68 & 2.50 \\
3P-N-B1 & 22 & 24.69 & 3.16 \\
3P-N-B2 & 27 & 26.28 & 3.12 \\
3P-N-B3 & 28 & 26.52 & 2.88 \\
3P-N-C1 & 14 & 23.97 & 3.09 \\
3P-N-C2 & 16 & 26.42 & 2.77 \\
3P-N-C3 & 20 & 28.53 & 3.09 \\
\hline
\end{tabular}

$\mathrm{f}_{\mathrm{c}}$ : cylinder compressive strength of concrete

$\mathrm{f}_{\mathrm{ct}}$ : axial tensile strength of concrete

509

510 Table 4 Mechanical properties of reinforcement

\begin{tabular}{ccc}
\hline$\varphi$ & $\begin{array}{c}\mathrm{f}_{\mathrm{y}} \\
(\mathrm{MPa})\end{array}$ & $\begin{array}{c}\mathrm{f}_{\mathrm{u}} \\
(\mathrm{MPa})\end{array}$ \\
\hline 8 & 570 & 677 \\
10 & 522.5 & 628.5 \\
12 & 527.5 & 627 \\
\hline $\begin{array}{l}\text { (mm) diameter of reinforcement } \\
\mathrm{f}_{\mathrm{y}} \text { : yield strength of }\end{array}$ \\
reinforcing steel in tension \\
$\begin{array}{l}\mathrm{f}_{\mathrm{u}} \text { : ultimate strength of } \\
\text { reinforcing steel in tension }\end{array}$
\end{tabular}

511

512 
514 Table 5 Summary of the experimental results

\begin{tabular}{cccccccccc}
\hline & & $\mathrm{P}_{\mathrm{y}, \mathrm{e}}$ & $\mathrm{P}_{\mathrm{u}, \mathrm{e}}$ & $\mathrm{P}_{\mathrm{u}, \mathrm{e}}$ & \multicolumn{6}{c}{ 解 } & \multicolumn{2}{c}{ Yielding of reinforcement } & Failure \\
Specimen & $\mathrm{v} / \mathrm{d}$ & $(\mathrm{kN})$ & $(\mathrm{kN})$ & $\frac{\mathrm{P}_{\mathrm{y}, \mathrm{e}}}{(\mathrm{mm})}$ & $\mathrm{A}_{\mathrm{sB}}$ & $\mathrm{A}_{\mathrm{sH}}$ & $\mathrm{A}_{\mathrm{sV}}$ & mode \\
\hline 3P-N-A1 & 1.68 & 395.2 & 444.9 & 1.13 & $*$ & YES & - & - & Brittle \\
3P-N-A2 & 1.68 & 433.2 & 534.1 & 1.23 & $*$ & YES & NO & - & Brittle \\
3P-N-A3 & 1.68 & 432.8 & 573.2 & 1.32 & 3.13 & YES & NO & NO & Brittle \\
3P-N-B1 & 1.12 & 586.0 & 660.4 & 1.13 & 2.66 & YES & - & - & Brittle \\
3P-N-B2 & 1.12 & 552.7 & 709.2 & 1.28 & 2.96 & YES & YES & - & Brittle \\
3P-N-B3 & 1.12 & 566.8 & 713.0 & 1.26 & 2.72 & YES & YES & NO & Brittle \\
3P-N-C1 & 0.84 & 601.5 & 799.8 & 1.33 & 3.13 & YES & - & - & Brittle \\
3P-N-C2 & 0.84 & 593.3 & 795.7 & 1.34 & 2.33 & YES & NO & - & Brittle \\
3P-N-C3 & 0.84 & 688.6 & 910.0 & 1.32 & 3.54 & YES & YES & YES & Ductile \\
\hline
\end{tabular}

$\mathrm{v} / \mathrm{d}$ : shear span-depth ratio; $\mathrm{P}_{\mathrm{y}, \mathrm{e}}$ : experimental yielding load; $\mathrm{P}_{\mathrm{u}, \mathrm{e}}$ : experimental failure load;

$\mathrm{u}_{\mathrm{z}}$ : vertical displacement; $\mathrm{A}_{\mathrm{sB}}$ : main bunched reinforcement;

$\mathrm{A}_{\mathrm{sH}}$ : horizontal secondary reinforcement; $\mathrm{A}_{\mathrm{sV}}$ : vertical secondary reinforcement

* Due to a failure in the data collection system these results are not available

516 Table 6 Coefficients for STM calibration

\begin{tabular}{|c|c|c|c|c|c|c|c|c|}
\hline \multirow[b]{2}{*}{ Specimen } & \multirow[b]{2}{*}{$\mathrm{v} / \mathrm{d}$} & \multirow{2}{*}{$\begin{array}{l}\theta_{\mathrm{d}} \\
\left({ }^{\circ}\right)\end{array}$} & \multirow{2}{*}{$\begin{array}{c}\text { STM } \\
\text { Reference } \\
\chi_{d}\end{array}$} & \multicolumn{2}{|c|}{ Experimental } & \multicolumn{2}{|c|}{ Souza } & \multirow{2}{*}{$\begin{array}{l}\text { Otsuki } \\
\chi_{u, \text { Otsuki }}\end{array}$} \\
\hline & & & & $\chi_{y, e}$ & $\chi_{\mathrm{u}, \mathrm{e}}$ & $\chi_{\mathrm{y}, \text { Souza }}$ & $\chi_{\mathrm{u}, \text { Souza }}$ & \\
\hline 3P-N-A1 & 1,68 & 23 & 0.983 & 0.740 & 0.832 & 1.88 & 2.05 & 1.371 \\
\hline 3P-N-A2 & 1,68 & 23 & 0.983 & 0.811 & 0.999 & 1.88 & 2.05 & 1.371 \\
\hline 3P-N-A3 & 1,68 & 23 & 0.983 & 0.810 & 1.073 & 1.88 & 2.05 & 1.371 \\
\hline 3P-N-B1 & 1,12 & 33 & 0.983 & 1.085 & 1.223 & 1.88 & 2.05 & 1.371 \\
\hline 3P-N-B2 & 1,12 & 33 & 0.983 & 1.024 & 1.314 & 1.88 & 2.05 & 1.371 \\
\hline 3P-N-B3 & 1,12 & 33 & 0.983 & 1.050 & 1.321 & 1.88 & 2.05 & 1.371 \\
\hline 3P-N-C1 & 0,84 & 40 & 0.983 & 1.081 & 1.438 & 1.88 & 2.05 & 1.310 \\
\hline 3P-N-C2 & 0,84 & 40 & 0.983 & 1.066 & 1.430 & 1.88 & 2.05 & 1.310 \\
\hline $3 \mathrm{P}-\mathrm{N}-\mathrm{C} 3$ & 0,84 & 40 & 0.983 & 1.238 & 1.636 & 1.88 & 2.05 & 1.310 \\
\hline
\end{tabular}

v/d: shear span-depth ratio; $\theta_{\mathrm{d}}$ : strut-tie angle given by design STM (Fig. 4); $\chi$-factor: coefficient for STM calibration; $\chi_{\mathrm{d}}: \chi$-factor for design acording to EHE-08 [18]; $\chi_{\mathrm{y}, \mathrm{e}}$ e experimental $\chi$-factor for yielding load; $\chi_{\mathrm{y}, \mathrm{e}}$ : experimental $\chi$-factor for ultimate load; $\chi_{y}$,souza: $\chi$-factor for yielding load proposed by Souza; $\chi_{\mathrm{u}, \text { Souza }}: \chi$-factor for ultimate load proposed by Souza; $\chi_{\mathrm{u}, \text { Otsuki }}: \chi$-factor for ultimate load proposed by Otsuki 
518 Table 7 Predicted and experimental failure loads

\begin{tabular}{|c|c|c|c|c|c|c|c|c|c|}
\hline \multirow[b]{2}{*}{ Specimen } & \multirow[b]{2}{*}{$\begin{array}{c}P_{u, e} \\
(k N)\end{array}$} & \multicolumn{2}{|c|}{ Bearing stress } & \multicolumn{4}{|c|}{ Punching Eurocode 2 [3] } & \multicolumn{2}{|c|}{ Punching proposal } \\
\hline & & $\begin{array}{c}P_{u, b} \\
(k N)\end{array}$ & $\frac{P_{u, e}}{P_{u, b}}$ & $\begin{array}{l}P_{\mathrm{u}, \mathrm{V} 0} \\
(\mathrm{kN})\end{array}$ & $\frac{P_{u, e}}{P_{u, V 0}}$ & $\begin{array}{l}P_{\mathrm{u}, \mathrm{V}} \\
(\mathrm{kN})\end{array}$ & $\frac{P_{u, e}}{P_{u, V}}$ & $\begin{array}{c}\mathrm{P}_{\mathrm{u}, \mathrm{V} \text { red }} \\
(\mathrm{kN})\end{array}$ & $\frac{\mathrm{P}_{\mathrm{u}, \mathrm{e}}}{\mathrm{P}_{\mathrm{u}, \mathrm{Vred}}}$ \\
\hline $3 \mathrm{P}-\mathrm{N}-\mathrm{A} 1$ & 444.9 & 622.5 & 0.71 & 334.8 & 1.33 & 632.0 & 0.70 & 459.8 & 0.97 \\
\hline $3 \mathrm{P}-\mathrm{N}-\mathrm{A} 2$ & 534.1 & 611.5 & 0.87 & 332.6 & 1.61 & 627.8 & 0.85 & 456.8 & 1.17 \\
\hline 3P-N-B1 & 660.4 & 655.5 & 1.01 & 356.0 & 1.85 & 1008.1 & 0.66 & 630.4 & 1.05 \\
\hline $3 \mathrm{P}-\mathrm{N}-\mathrm{B} 2$ & 709.2 & 692.5 & 1.02 & 363.5 & 1.95 & 1029.2 & 0.69 & 643.6 & 1.10 \\
\hline $3 \mathrm{P}-\mathrm{N}-\mathrm{C} 1$ & 799.8 & 638.2 & 1.25 & 368.3 & 2.17 & 1390.5 & 0.58 & 798.4 & 1.00 \\
\hline $3 \mathrm{P}-\mathrm{N}-\mathrm{C} 2$ & 795.7 & 695.9 & 1.14 & 380.5 & 2.09 & 1436.4 & 0.55 & 824.7 & 0.96 \\
\hline 3P-N-A3 & 573.2 & 631.4 & 0.91 & 564.6 & 1.02 & 788.6 & 0.73 & 658.8 & 0.87 \\
\hline 3P-N-B3 & 713.0 & 698.2 & 1.02 & 611.6 & 1.17 & 1112.5 & 0.64 & 822.3 & 0.87 \\
\hline 3P-N-C3 & 910.0 & 744.4 & 1.22 & 656.9 & 1.39 & 1473.6 & 0.62 & 998.7 & 0.91 \\
\hline
\end{tabular}

$\mathrm{P}_{\mathrm{u}, \mathrm{e}}$ : Experimental ultimate load; $\mathrm{P}_{\mathrm{u}, \mathrm{b}}$ : Maximum column bearing load;

$\mathrm{P}_{\mathrm{u}, \mathrm{V} 0}$ : Ultimate punching load by Eurocode 2 [16], not considering the shear enhancement factor;

$\mathrm{P}_{\mathrm{u}, \mathrm{V}}$ : Ultimate punching load by Eurocode $2[16]$;

$\mathrm{P}_{\mathrm{u}, \text { Vred }}$ : Reduced ultimate punching load based on Eurocode 2 [16] 
521 Table 8 Comparison between the experimental results of three-pile caps database, the classic STM 522 formulation and the proposed STM-punching formulation

\begin{tabular}{|c|c|c|c|c|c|c|c|c|c|c|c|c|}
\hline & \multirow[b]{2}{*}{ Specimen } & \multicolumn{4}{|c|}{ Geometrical and material properties, experimental failure load } & \multicolumn{2}{|c|}{ STM Fig. $15 \mathrm{a}$} & \multicolumn{5}{|c|}{ Proposed STM-punching formulation Fig. 15b } \\
\hline & & $\begin{array}{c}\text { As } \\
\left(\mathrm{cm}^{2}\right)\end{array}$ & $\begin{array}{c}\mathrm{e} / \phi / \mathrm{c} / \mathrm{v} / \mathrm{d} \\
(\mathrm{cm})\end{array}$ & $\begin{array}{c}\mathrm{f}_{\mathrm{c}} / \mathrm{f}_{\mathrm{y}} \\
(\mathrm{MPa})\end{array}$ & $\begin{array}{l}\mathrm{P}_{\mathrm{u}, \mathrm{e}} \\
(\mathrm{kN})\end{array}$ & $\begin{array}{c}\mathrm{P}_{\mathrm{u}, \mathrm{STM}(\mathrm{\chi d})} \\
(\mathrm{kN})\end{array}$ & $\frac{\mathrm{P}_{\mathrm{u}, \mathrm{e}}}{\mathrm{P}_{\mathrm{u}, \mathrm{STM}(\mathrm{d})}}$ & $\begin{array}{l}\mathrm{a}_{\mathrm{v}} / \mathrm{u} \\
(\mathrm{cm})\end{array}$ & $\begin{array}{c}\mathrm{P}_{\mathrm{u}, \mathrm{STM}}(\mathrm{\chi u}, \text { Otsuki) } \\
(\mathrm{kN})\end{array}$ & $\begin{array}{c}P_{\mathrm{u}, \mathrm{Vred}} \\
(\mathrm{kN})\end{array}$ & $\begin{array}{l}\mathrm{P}_{\mathrm{u}, \mathrm{SV}} \\
(\mathrm{kN})\end{array}$ & $\frac{\mathrm{P}_{\mathrm{u}, \mathrm{e}}}{\mathrm{P}_{\mathrm{u}, \mathrm{SV}}}$ \\
\hline \multirow{9}{*}{ 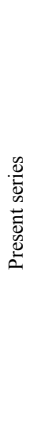 } & 3P-N-A1 & 4.52 (B) & $0.80 / 0.25 / 0.25 / 0.34 / 0.20$ & $23.3 / 525.0$ & 444.9 & 456.8 & 0.97 & $0.21 / 0.59$ & 637.1 & 306.5 & 306.5 & 1.45 \\
\hline & 3P-N-A2 & 4.52 (B) & $0.80 / 0.25 / 0.25 / 0.34 / 0.20$ & $22.9 / 525.0$ & 534.1 & 456.8 & 1.17 & $0.21 / 0.59$ & 637.1 & 304.5 & 304.5 & 1.75 \\
\hline & 3P-N-A3 & $4.52(\mathrm{~B})+2.01(\mathrm{~V})$ & $0.80 / 0.25 / 0.25 / 0.34 / 0.20$ & $23.7 / 525.0$ & 573.2 & 456.8 & 1.25 & $0.21 / 0.59$ & 637.1 & 502.6 & 502.6 & 1.14 \\
\hline & 3P-N-B1 & 3.05 (B) & $0.80 / 0.25 / 0.25 / 0.34 / 0.30$ & $24.7 / 525.0$ & 660.4 & 461.5 & 1.43 & $0.21 / 0.59$ & 643.7 & 420.3 & 420.3 & 1.57 \\
\hline & 3P-N-B2 & 3.05 (B) & $0.80 / 0.25 / 0.25 / 0.34 / 0.30$ & $26.3 / 525.0$ & 709.2 & 461.5 & 1.54 & $0.21 / 0.59$ & 643.7 & 429.0 & 429.0 & 1.65 \\
\hline & 3P-N-B3 & $3.05(\mathrm{~B})+2.01(\mathrm{~V})$ & $0.80 / 0.25 / 0.25 / 0.34 / 0.30$ & $26.5 / 525.0$ & 713.0 & 461.5 & 1.54 & $0.21 / 0.59$ & 643.7 & 616.8 & 616.8 & 1.16 \\
\hline & 3P-N-C1 & 2.36 (B) & $0.80 / 0.25 / 0.25 / 0.34 / 0.40$ & $24.0 / 525.0$ & 799.8 & 475.6 & 1.68 & $0.21 / 0.59$ & 633.9 & 590.7 & 590.7 & 1.35 \\
\hline & $3 \mathrm{P}-\mathrm{N}-\mathrm{C} 2$ & 2.36 (B) & $0.80 / 0.25 / 0.25 / 0.34 / 0.40$ & $26.4 / 525.0$ & 795.7 & 475.6 & 1.67 & $0.21 / 0.59$ & 633.9 & 620.2 & 620.2 & 1.28 \\
\hline & 3P-N-C3 & $2.36(\mathrm{~B})+2.01(\mathrm{~V})$ & $0.80 / 0.25 / 0.25 / 0.34 / 0.40$ & $28.5 / 525.0$ & 910.0 & 475.6 & 1.91 & $0.21 / 0.59$ & 633.9 & 800.0 & 633.9 & 1.44 \\
\hline \multirow{21}{*}{ 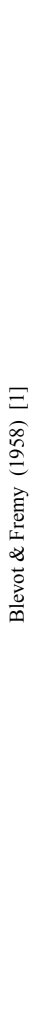 } & $3 \mathrm{~N} 1$, bis & $19.63(\mathrm{~B})+6.28(\mathrm{M})$ & $1.20 / 0.35 / 0.45 / 0.47 / 0.49$ & $45.4 / 445.0$ & 4905.0 & 3442.7 & 1.42 & $0.23 / 0.94$ & 4869.3 & 2308.0 & 2308.0 & 2.13 \\
\hline & $3 \mathrm{~N} 2$, bis & $19.63(\mathrm{~B})+6.79(\mathrm{R})$ & $1.20 / 0.35 / 0.45 / 0.47 / 0.49$ & $43.7 / 442.0$ & 4414.5 & 2886.2 & 1.53 & $0.23 / 0.94$ & 4082.2 & 2858.0 & 2858.0 & 1.54 \\
\hline & $3 \mathrm{~N} 3$, bis & $19.63(\mathrm{~B})+6.28(\mathrm{M})$ & $1.20 / 0.35 / 0.45 / 0.47 / 0.74$ & $40.9 / 436.0$ & 5689.8 & 5094.0 & 1.12 & $0.23 / 0.94$ & 6556.6 & 3776.1 & 3776.1 & 1.51 \\
\hline & $3 \mathrm{~N} 4$, bis & $19.63(\mathrm{~B})+6.79(\mathrm{R})$ & $1.20 / 0.35 / 0.45 / 0.47 / 0.74$ & $42.5 / 434.0$ & 7063.2 & 4279.9 & 1.65 & $0.23 / 0.94$ & 5508.7 & 5499.1 & 5499.1 & 1.28 \\
\hline & 6,1 & 3.39 (B) & $0.42 / 0.14 / 0.15 / 0.17 / 0.28$ & $37.4 / 474.3$ & 1118.3 & 874.0 & 1.28 & $0.08 / 0.31$ & 1105.1 & 741.7 & 741.7 & 1.51 \\
\hline & 6,2 & 3.39 (B) & $0.42 / 0.14 / 0.15 / 0.17 / 0.27$ & $32.5 / 481.3$ & 1098.7 & 845.2 & 1.30 & $0.08 / 0.31$ & 1074.8 & 664.5 & 664.5 & 1.65 \\
\hline & 6,3 & $2.26(\mathrm{~B})+1.57(\mathrm{M})$ & $0.42 / 0.14 / 0.15 / 0.17 / 0.25$ & $36.4 / 483.8$ & 1157.6 & 748.9 & 1.55 & $0.08 / 0.31$ & 961.5 & 625.1 & 625.1 & 1.85 \\
\hline & 6,3 bis & $1.57(\mathrm{~B})+2.26(\mathrm{M})$ & $0.42 / 0.14 / 0.15 / 0.17 / 0.26$ & $25.0 / 504.6$ & 939.3 & 727.2 & 1.29 & $0.08 / 0.31$ & 929.7 & 551.8 & 551.8 & 1.70 \\
\hline & $7 \mathrm{~N}, 5$ & 3.39 (B) & $0.42 / 0.14 / 0.15 / 0.17 / 0.27$ & $23.8 / 493.5$ & 882.9 & 853.8 & 1.03 & $0.08 / 0.31$ & 1088.3 & 587.4 & 587.4 & 1.50 \\
\hline & $7 \mathrm{~N}, 6$ & 6.03 (B) & $0.42 / 0.14 / 0.15 / 0.17 / 0.26$ & $23.8 / 465.5$ & 1030.1 & 1425.0 & 0.72 & $0.08 / 0.31$ & 1817.9 & 706.8 & 706.8 & 1.46 \\
\hline & 8 bis, 1 & 2.58 (B) & $0.42 / 0.14 / 0.15 / 0.17 / 0.23$ & $29.5 / 446.0$ & 735.8 & 509.2 & 1.44 & $0.08 / 0.31$ & 665.2 & 479.9 & 479.9 & 1.53 \\
\hline & 8 bis, 2 & $4.52(\mathrm{M})$ & $0.42 / 0.14 / 0.15 / 0.17 / 0.23$ & $29.1 / 462.3$ & 532.2 & 524.0 & 1.02 & $0.08 / 0.31$ & 687.3 & 467.2 & 467.2 & 1.14 \\
\hline & 8 bis, 3 & $1.29(\mathrm{~B})+2.26(\mathrm{M})$ & $0.42 / 0.14 / 0.15 / 0.17 / 0.22$ & $29.5 / 457.8$ & 669.5 & 501.9 & 1.33 & $0.08 / 0.31$ & 661.7 & 452.8 & 452.8 & 1.48 \\
\hline & $13, \mathrm{c}$ & 3.14 (B) & $0.42 / 0.14 / 0.15 / 0.17 / 0.20$ & $39.8 / 458.0$ & 678.9 & 546.9 & 1.24 & $0.08 / 0.31$ & 737.6 & 465.4 & 465.4 & 1.46 \\
\hline & $13, \mathrm{~d}$ & 3.14 (B) & $0.42 / 0.14 / 0.15 / 0.17 / 0.20$ & $39.6 / 457.0$ & 627.8 & 543.2 & 1.16 & $0.08 / 0.31$ & 733.4 & 461.5 & 461.5 & 1.36 \\
\hline & $13, \mathrm{~g}$ & $1.57(\mathrm{~B})+1.57(\mathrm{M})$ & $0.42 / 0.14 / 0.15 / 0.17 / 0.21$ & $37.1 / 458.0$ & 618.0 & 446.6 & 1.38 & $0.08 / 0.31$ & 597.6 & 439.8 & 439.8 & 1.41 \\
\hline & $13, \mathrm{~h}$ & $1.57(\mathrm{~B})+1.57(\mathrm{M})$ & $0.42 / 0.14 / 0.15 / 0.17 / 0.19$ & $23.9 / 456.7$ & 442.4 & 421.2 & 1.05 & $0.08 / 0.31$ & 570.8 & 351.6 & 351.6 & 1.26 \\
\hline & $14, \mathrm{c}$ & 3.14 (B) & $0.42 / 0.14 / 0.15 / 0.17 / 0.28$ & $33.5 / 465.3$ & 784.8 & 774.1 & 1.01 & $0.08 / 0.31$ & 981.0 & 673.2 & 673.2 & 1.17 \\
\hline & $14, \mathrm{~d}$ & 3.14 (B) & $0.42 / 0.14 / 0.15 / 0.17 / 0.27$ & $34.4 / 465.0$ & 787.3 & 757.1 & 1.04 & $0.08 / 0.31$ & 962.6 & 660.6 & 660.6 & 1.19 \\
\hline & $14, \mathrm{~g}$ & $1.57(\mathrm{~B})+1.57(\mathrm{M})$ & $0.42 / 0.14 / 0.15 / 0.17 / 0.27$ & $27.0 / 471.3$ & 836.3 & 613.9 & 1.36 & $0.08 / 0.31$ & 778.8 & 573.6 & 573.6 & 1.46 \\
\hline & $14, \mathrm{~h}$ & $1.57(\mathrm{~B})+1.57(\mathrm{M})$ & $0.42 / 0.14 / 0.15 / 0.17 / 0.28$ & $23.9 / 496.0$ & 803.9 & 658.1 & 1.22 & $0.08 / 0.31$ & 832.6 & 563.9 & 563.9 & 1.43 \\
\hline \multirow{9}{*}{ 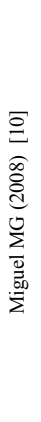 } & B20A1/1 & 3.68 (B) & $0.96 / 0.20 / 0.35 / 0.38 / 0.50$ & $27.4 / 591.0$ & 1512.0 & 917.2 & 1.65 & $0.25 / 0.87$ & 1214.8 & 964.2 & 964.2 & 1.57 \\
\hline & $\mathrm{B} 20 \mathrm{~A} 1 / 2$ & 3.68 (B) & $0.96 / 0.20 / 0.35 / 0.38 / 0.50$ & $33.0 / 591.0$ & 1648.0 & 917.2 & 1.80 & $0.25 / 0.87$ & 1214.8 & 1058.2 & 1058.2 & 1.56 \\
\hline & B30A1 & 3.68 (B) & $0.96 / 0.30 / 0.35 / 0.38 / 0.50$ & $31.0 / 591.0$ & 1909.0 & 917.2 & 2.08 & $0.20 / 0.87$ & 1214.8 & 1314.2 & 1214.8 & 1.57 \\
\hline & B20A2 & $3.68(\mathrm{~B})+2.45(\mathrm{M})$ & $0.96 / 0.20 / 0.35 / 0.38 / 0.50$ & $35.5 / 591.0$ & 2083.0 & 1270.3 & 1.64 & $0.25 / 0.87$ & 1682.4 & 1097.5 & 1097.5 & 1.90 \\
\hline & $\mathrm{B} 30 \mathrm{~A} 2$ & $3.68(\mathrm{~B})+2.45(\mathrm{M})$ & $0.96 / 0.30 / 0.35 / 0.38 / 0.50$ & $40.3 / 591.0$ & 2674.0 & 1270.3 & 2.11 & $0.20 / 0.87$ & 1682.4 & 1498.4 & 1498.4 & 1.78 \\
\hline & $\mathrm{B} 20 \mathrm{~A} 3$ & $3.68(\mathrm{~B})+3.12(\mathrm{R})$ & $0.96 / 0.20 / 0.35 / 0.38 / 0.50$ & $37.9 / 591.0$ & 1945.0 & 917.2 & 2.12 & $0.25 / 0.87$ & 1214.8 & 2091.9 & 1214.8 & 1.60 \\
\hline & $\mathrm{B} 30 \mathrm{~A} 3$ & $3.68(\mathrm{~B})+3.12(\mathrm{R})$ & $0.96 / 0.30 / 0.35 / 0.38 / 0.50$ & $24.5 / 591.0$ & 1938.0 & 917.2 & 2.11 & $0.20 / 0.87$ & 1214.8 & 2317.7 & 1214.8 & 1.60 \\
\hline & B20A4 & $3.68(\mathrm{~B})+3.12(\mathrm{R})+2.00(\mathrm{~V})$ & $0.96 / 0.20 / 0.35 / 0.38 / 0.50$ & $35.6 / 591.0$ & 2375.0 & 917.2 & 2.59 & $0.25 / 0.87$ & 1214.8 & 2048.7 & 1214.8 & 1.96 \\
\hline & B30A4 & $3.68(\mathrm{~B})+3.12(\mathrm{R})+2.00(\mathrm{~V})$ & $0.96 / 0.30 / 0.35 / 0.38 / 0.50$ & $24.6 / 591.0$ & 2283.0 & 917.2 & 2.49 & $0.20 / 0.87$ & 1214.8 & 2320.9 & 1214.8 & 1.88 \\
\hline
\end{tabular}

As: reinforcement considered for STM or punching calculations (per side or direction) - (B): bunched; (V): vertical; (M): median; (R): rectangular mesh

e: pile spacing between axis; $\phi$ : pile diameter/side; c: column diameter/side; v: shear span; d: effective depth;

$\mathrm{f}_{\mathrm{c}}$ : cylinder compressive strength of concrete; $\mathrm{f}_{\mathrm{y}}$ : yield strength of reinforcing steel in tension; $\mathrm{P}_{\mathrm{u}, \mathrm{e}}$ : ultimate experimental load;

$\mathrm{P}_{\mathrm{u}, \mathrm{STM}(\mathrm{Xd})}$ : ultimate load predicted by the reference STM; $\mathrm{a}_{\mathrm{v}}$ : distance between column and pile edges; u: basic control perimeter;

$\mathrm{P}_{\mathrm{u}, \mathrm{STM}\left(\mathrm{Xu}_{\mathrm{u}} \text { Otsuki) }\right.}$ : ultimate load predicted by Otsuki [26]; $\mathrm{P}_{\mathrm{u}, \mathrm{Vred}}:$ Reduced ultimate punching load based on Eurocode 2 [16]; $\mathrm{P}_{\mathrm{u}, \mathrm{Sv}}$ : Ultimate load proposed by authors 
523 Table 9 Comparison of the experimental results of the four-pile caps database, the classic STM 524 formulation and the proposed STM-punching formulation

\begin{tabular}{|c|c|c|c|c|c|c|c|c|c|c|c|c|}
\hline & & Geometrical and me & aterial properties, experime & tal failure lo & & STM Fi & ig. 16a & Proposed S & TM-punching fe & formulatio & Fig. & \\
\hline & Specimen & $\begin{array}{c}\text { As } \\
\left(\mathrm{cm}^{2}\right)\end{array}$ & $\begin{array}{c}\mathrm{e} / \phi / \mathrm{c} / \mathrm{v} / \mathrm{d} \\
(\mathrm{cm})\end{array}$ & $\begin{array}{l}\mathrm{f}_{\mathrm{c}} / \mathrm{f}_{\mathrm{y}} \\
(\mathrm{MPa})\end{array}$ & $\begin{array}{ll}\mathrm{P}_{\mathrm{u}, \mathrm{e}} & \mathrm{P} \\
(\mathrm{kN}) & \end{array}$ & $\begin{array}{c}\mathrm{P}_{\mathrm{u}, \mathrm{STM}(\mathrm{xd})} \\
(\mathrm{kN})\end{array}$ & $\frac{\mathrm{P}_{\mathrm{u}, \mathrm{e}}}{\mathrm{P}_{\mathrm{u}, \mathrm{STM}(\mathrm{Xd})}}$ & $\begin{array}{l}\mathrm{a}_{\mathrm{v}} / \mathrm{u} \\
(\mathrm{cm})\end{array}$ & $\begin{array}{c}\mathrm{P}_{\mathrm{u}, \mathrm{STM}(\mathrm{\alpha u}, \text { Otsuki }} \\
(\mathrm{kN})\end{array}$ & $\begin{array}{c}\mathrm{P}_{\mathrm{u}, \text { Vred }} \\
(\mathrm{kN})\end{array}$ & $\begin{array}{l}P_{u, S V} \\
(k N)\end{array}$ & $\frac{P_{u, e}}{P_{u, S V}}$ \\
\hline & 1,1 & $2.01(\mathrm{~B})$ & $0.80 / 0.25 / 0.25 / 0.34 / 0.20$ & $23.3 / 525.0$ & 444.9 & 362.9 & 2.30 & $0.13 / 0.39$ & 485.4 & 416.0 & 416.0 & 2.00 \\
\hline & 1,2 & 3.14 (D) & $0.42 / 0.14 / 0.15 / 0.17 / 0.26$ & $27.9 / 0.0$ & 863.3 & 424.0 & 2.04 & $0.13 / 0.39$ & 564.5 & 438.1 & 438.1 & 1.97 \\
\hline & 1,3 & $1.01(\mathrm{~B})+1.57(\mathrm{D})$ & $0.42 / 0.14 / 0.15 / 0.17 / 0.25$ & $31.3 / 439.7$ & 853.5 & 390.5 & 2.19 & $0.13 / 0.39$ & 521.6 & 437.5 & 437.5 & 1.95 \\
\hline & 1,4 & $1.01(\mathrm{~B})$ & $0.42 / 0.14 / 0.15 / 0.17 / 0.27$ & $31.9 / 439.9$ & 622.9 & 196.0 & 3.18 & $0.13 / 0.39$ & 259.0 & 455.5 & 259.0 & 2.41 \\
\hline & 1,4 bis & 2.01 (B) & $0.42 / 0.14 / 0.15 / 0.17 / 0.26$ & $29.1 / 478.0$ & 703.9 & 402.4 & 1.75 & $0.13 / 0.39$ & 536.5 & 425.5 & 425.5 & 1.65 \\
\hline & $1 \mathrm{~A}, 1$ & 3.83 (B) & $0.42 / 0.14 / 0.15 / 0.17 / 0.27$ & $26.6 / 494.5$ & 1128.2 & 840.2 & 1.34 & $0.13 / 0.39$ & 1109.8 & 546.6 & 546.6 & 2.06 \\
\hline & $1 \mathrm{~A}, 2$ & 5.34 (D) & $0.42 / 0.14 / 0.15 / 0.17 / 0.27$ & $36.8 / 0.0$ & 882.9 & 842.3 & 1.05 & $0.13 / 0.39$ & 1112.6 & 606.1 & 606.1 & 1.46 \\
\hline & $1 \mathrm{~A}, 2 \mathrm{bis}$ & 5.34 (D) & $0.42 / 0.14 / 0.15 / 0.17 / 0.27$ & $33.3 / 0.0$ & 1155.1 & 842.3 & 1.37 & $0.13 / 0.39$ & 1112.6 & 586.0 & 586.0 & 1.97 \\
\hline & $1 \mathrm{~A}, 3$ & $1.92(\mathrm{~B})+1.92(\mathrm{D})$ & $0.42 / 0.14 / 0.15 / 0.17 / 0.27$ & $36.6 / 523.0$ & 1162.5 & 736.2 & 1.58 & $0.13 / 0.39$ & 972.4 & 576.7 & 576.7 & 2.02 \\
\hline & $1 \mathrm{~A}, 4$ & $3.83(\mathrm{~B})$ & $0.42 / 0.14 / 0.15 / 0.17 / 0.27$ & $32.9 / 498.0$ & 1135.5 & 846.1 & 1.34 & $0.13 / 0.39$ & 1117.6 & 586.8 & 586.8 & 1.94 \\
\hline & $\mathrm{Q}, 1$ & $4.02(\mathrm{R})$ & $0.42 / 0.14 / 0.15 / 0.17 / 0.19$ & $33.9 / 459.5$ & 400.2 & 294.3 & 1.36 & $0.13 / 0.39$ & 414.3 & 300.2 & 300.2 & 1.33 \\
\hline$\Xi$ & 6,5 & $4.52(\mathrm{~B})$ & $0.42 / 0.14 / 0.15 / 0.17 / 0.26$ & $18.4 / 517.5$ & 826.5 & 999.3 & 0.83 & $0.13 / 0.39$ & 1328.1 & 489.2 & 489.2 & 1.69 \\
\hline$\stackrel{2}{2}$ & 6,6 & 8.04 (B) & $0.42 / 0.14 / 0.15 / 0.17 / 0.28$ & $18.4 / 468.0$ & 794.6 & 1730.3 & 0.46 & $0.13 / 0.39$ & 2272.8 & 645.6 & 645.6 & 1.23 \\
\hline હे & $9, \mathrm{~A} 1$ & $4.52(\mathrm{~B})$ & $0.42 / 0.14 / 0.15 / 0.17 / 0.47$ & $27.3 / 459.0$ & 1177.2 & 1602.3 & 0.73 & $0.13 / 0.39$ & 2104.7 & 1147.0 & 1147.0 & 1.03 \\
\hline 崖 & $9, \mathrm{~A} 2$ & 8.04 (B) & $0.42 / 0.14 / 0.15 / 0.17 / 0.47$ & $40.8 / 467.0$ & 1863.9 & 2898.2 & 0.64 & $0.13 / 0.39$ & 3806.9 & 1589.4 & 1589.4 & 1.17 \\
\hline$\frac{\vec{a}}{m}$ & $10,1 \mathrm{a}$ & $4.52(\mathrm{~B})$ & $0.42 / 0.14 / 0.15 / 0.17 / 0.23$ & $34.6 / 446.0$ & 833.9 & 761.9 & 1.09 & $0.13 / 0.39$ & 1034.8 & 525.9 & 525.9 & 1.59 \\
\hline & $10,1 \mathrm{~b}$ & $2.26(\mathrm{~B})+3.08(\mathrm{D})$ & $0.42 / 0.14 / 0.15 / 0.17 / 0.22$ & $43.1 / 455.0$ & 784.8 & 749.2 & 1.05 & $0.13 / 0.39$ & 1026.3 & 535.4 & 535.4 & 1.47 \\
\hline & $10,2 \mathrm{a}$ & $4.52(\mathrm{~B})$ & $0.42 / 0.14 / 0.15 / 0.17 / 0.22$ & $33.9 / 453.3$ & 735.8 & 740.7 & 0.99 & $0.13 / 0.39$ & 1014.7 & 497.5 & 497.5 & 1.48 \\
\hline & $10,2 \mathrm{~b}$ & $2.26(B)+3.08(D)$ & $0.42 / 0.14 / 0.15 / 0.17 / 0.22$ & $31.4 / 462.0$ & 784.8 & 754.9 & 1.04 & $0.13 / 0.39$ & 1034.2 & 481.9 & 481.9 & 1.63 \\
\hline & $10,3 \mathrm{a}$ & $4.52(B)$ & $0.42 / 0.14 / 0.15 / 0.17 / 0.22$ & $28.4 / 462.0$ & 745.6 & 754.9 & 0.99 & $0.13 / 0.39$ & 1034.2 & 468.7 & 468.7 & 1.59 \\
\hline & $10,3 b$ & $2.26(\mathrm{~B})+3.08(\mathrm{D})$ & $0.42 / 0.14 / 0.15 / 0.17 / 0.22$ & $33.4 / 463.5$ & 725.9 & 756.1 & 0.96 & $0.13 / 0.39$ & 1035.9 & 491.6 & 491.6 & 1.48 \\
\hline & $11,2 \mathrm{a}$ & 3.14 (B) & $0.42 / 0.14 / 0.15 / 0.17 / 0.29$ & $30.9 / 444.7$ & 546.9 & 665.2 & 0.82 & $0.13 / 0.39$ & 873.7 & 584.2 & 584.2 & 0.94 \\
\hline & $11,2 \mathrm{~b}$ & 3.14 (B) & $0.42 / 0.14 / 0.15 / 0.17 / 0.27$ & $30.0 / 440.7$ & 573.9 & 613.7 & 0.94 & $0.13 / 0.39$ & 810.7 & 532.5 & 532.5 & 1.08 \\
\hline & $4 \mathrm{~N} 1 \mathrm{bis}$ & $19.63(\mathrm{~B})+7.92(\mathrm{R})$ & $1.20 / 0.35 / 0.50 / 0.44 / 0.68$ & $40.8 / 479.6$ & 6572.7 & 4546.9 & 1.45 & $0.37 / 0.89$ & 6322.0 & 3119.6 & 3119.6 & 2.11 \\
\hline & $4 \mathrm{~N} 2$ bis & $14.73(\mathrm{~B})+12.57$ (D) & $1.20 / 0.35 / 0.50 / 0.44 / 0.67$ & $34.2 / 486.3$ & 7249.6 & 2835.4 & 2.56 & $0.37 / 0.89$ & 3955.6 & 2958.9 & 2958.9 & 2.45 \\
\hline & $4 \mathrm{~N} 3$ bis & $16.1(\mathrm{~B})+6.28(\mathrm{R})$ & $1.20 / 0.35 / 0.50 / 0.44 / 0.92$ & $49.3 / 453.3$ & 8829.0 & 4742.9 & 1.86 & $0.37 / 0.89$ & 6378.6 & 4585.6 & 4585.6 & 1.93 \\
\hline & $4 \mathrm{~N} 4$ bis & $12.57(\mathrm{~B})+12.57$ (D) & $1.20 / 0.35 / 0.50 / 0.44 / 0.92$ & $42.3 / 486.4$ & 8583.8 & 3323.3 & 2.58 & $0.37 / 0.89$ & 4469.5 & 4628.0 & 4469.5 & 1.92 \\
\hline & A1 & $7.85(\mathrm{R})$ & $0.60 / 0.20 / 0.20 / 0.25 / 0.42$ & $26.6 / 410.0$ & 1110.0 & 759.1 & 1.46 & $0.21 / 0.64$ & 988.3 & 810.2 & 810.2 & 1.37 \\
\hline & A2 & 3.93 (B) & $0.60 / 0.20 / 0.20 / 0.25 / 0.42$ & $34.0 / 410.0$ & 1420.0 & 759.1 & 1.87 & $0.21 / 0.64$ & 988.3 & 916.0 & 916.0 & 1.55 \\
\hline & A4 & $7.85(\mathrm{R})$ & $0.60 / 0.20 / 0.20 / 0.25 / 0.42$ & $26.7 / 410.0$ & 1230.0 & 759.1 & 1.62 & $0.21 / 0.64$ & 988.3 & 811.7 & 811.7 & 1.52 \\
\hline & A5 & 3.93 (B) & $0.60 / 0.20 / 0.20 / 0.25 / 0.42$ & $33.2 / 410.0$ & 1400.0 & 759.1 & 1.84 & $0.21 / 0.64$ & 988.3 & 905.1 & 905.1 & 1.55 \\
\hline & A7 & $7.85(\mathrm{R})$ & $0.60 / 0.20 / 0.20 / 0.25 / 0.42$ & $30.2 / 410.0$ & 1640.0 & 759.1 & 2.16 & $0.21 / 0.64$ & 988.3 & 863.3 & 863.3 & 1.90 \\
\hline 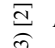 & A8 & 3.93 (B) & $0.60 / 0.20 / 0.20 / 0.25 / 0.42$ & $34.0 / 410.0$ & 1510.0 & 759.1 & 1.99 & $0.21 / 0.64$ & 988.3 & 916.0 & 916.0 & 1.65 \\
\hline$\stackrel{0}{=}$ & A9 & $7.85(\mathrm{R})$ & $0.60 / 0.20 / 0.20 / 0.25 / 0.42$ & $33.2 / 410.0$ & 1450.0 & 759.1 & 1.91 & $0.21 / 0.64$ & 988.3 & 905.1 & 905.1 & 1.60 \\
\hline 䇏 & $\mathrm{A} 10$ & $7.85(\mathrm{R})$ & $0.60 / 0.20 / 0.20 / 0.25 / 0.42$ & $23.5 / 410.0$ & 1520.0 & 759.1 & 2.00 & $0.21 / 0.64$ & 988.3 & 761.5 & 761.5 & 2.00 \\
\hline & A11 & $7.85(\mathrm{R})$ & $0.60 / 0.20 / 0.20 / 0.25 / 0.42$ & $22.5 / 410.0$ & 1640.0 & 759.1 & 2.16 & $0.21 / 0.64$ & 988.3 & 745.1 & 745.1 & 2.20 \\
\hline & $\mathrm{A} 12$ & $7.85(\mathrm{R})$ & $0.60 / 0.20 / 0.20 / 0.25 / 0.42$ & $31.6 / 410.0$ & 1640.0 & 759.1 & 2.16 & $0.21 / 0.64$ & 988.3 & 883.0 & 883.0 & 1.86 \\
\hline & B1 & $6.28(\mathrm{R})$ & $0.40 / 0.20 / 0.20 / 0.13 / 0.42$ & $33.4 / 410.0$ & 2080.0 & 986.6 & 2.11 & $0.07 / 0.54$ & 1376.1 & 2008.3 & 1376.1 & 1.51 \\
\hline & B2 & $7.85(\mathrm{R})$ & $0.40 / 0.20 / 0.20 / 0.13 / 0.42$ & $30.8 / 410.0$ & 1870.0 & 1233.2 & 1.52 & $0.07 / 0.54$ & 1720.1 & 1952.8 & 1720.1 & 1.09 \\
\hline & B3 & $4.71(\mathrm{R})$ & $0.40 / 0.20 / 0.20 / 0.13 / 0.42$ & $43.7 / 410.0$ & 1770.0 & 739.9 & 2.39 & $0.07 / 0.54$ & 1032.0 & 2297.1 & 1032.0 & 1.72 \\
\hline$\overbrace{2}^{\infty}$ & BPC-25-1 & 3.57 (B) & $0.54 / 0.15 / 0.30 / 0.16 / 0.20$ & $18.9 / 413.0$ & 818.0 & 414.3 & 1.97 & $0.14 / 0.56$ & 731.1 & 414.9 & 414.9 & 1.97 \\
\hline$\overline{\bar{\sigma}} \bar{\sigma}$ & BPC-25-2 & 3.57 (B) & $0.54 / 0.15 / 0.30 / 0.16 / 0.20$ & $22.0 / 413.0$ & 813.0 & 414.3 & 1.96 & $0.14 / 0.56$ & 731.1 & 436.4 & 436.4 & 1.86 \\
\hline 吾 & BPC-30-30-1 & $2.85(\mathrm{~B})$ & $0.50 / 0.15 / 0.30 / 0.14 / 0.25$ & $28.9 / 405.0$ & 1039.0 & 449.0 & 2.31 & $0.11 / 0.48$ & 736.7 & 650.9 & 650.9 & 1.60 \\
\hline 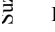 & BPC-30-30-2 & 2.85 (B) & $0.50 / 0.15 / 0.30 / 0.14 / 0.25$ & $30.9 / 405.0$ & 1029.0 & 449.0 & 2.29 & $0.11 / 0.48$ & 736.7 & 665.6 & 665.6 & 1.55 \\
\hline
\end{tabular}




\begin{tabular}{|c|c|c|c|c|c|c|c|c|c|c|c|c|}
\hline & BPC-30-25-1 & $2.85(\mathrm{~B})$ & $0.50 / 0.15 / 0.25 / 0.16 / 0.25$ & $29.1 / 405.0$ & 853.0 & 426.6 & 2.00 & $0.14 / 0.50$ & 646.8 & 530.0 & 530.0 & 1.61 \\
\hline & BP-25-1 & $7.13(\mathrm{R})$ & $0.54 / 0.15 / 0.30 / 0.16 / 0.20$ & $22.6 / 413.0$ & 735.0 & 414.3 & 1.77 & $0.14 / 0.56$ & 731.1 & 411.6 & 411.6 & 1.79 \\
\hline & BP-25-2 & $7.13(\mathrm{R})$ & $0.54 / 0.15 / 0.30 / 0.16 / 0.20$ & $21.5 / 413.0$ & 755.0 & 414.3 & 1.82 & $0.14 / 0.56$ & 731.1 & 404.8 & 404.8 & 1.87 \\
\hline & BP-30-30-1 & $5.7(\mathrm{R})$ & $0.50 / 0.15 / 0.30 / 0.14 / 0.25$ & $27.3 / 405.0$ & 916.0 & 449.0 & 2.04 & $0.11 / 0.48$ & 736.7 & 578.6 & 578.6 & 1.58 \\
\hline & BP-30-30-2 & $5.7(\mathrm{R})$ & $0.50 / 0.15 / 0.30 / 0.14 / 0.25$ & $28.5 / 405.0$ & 907.0 & 449.0 & 2.02 & $0.11 / 0.48$ & 736.7 & 587.0 & 587.0 & 1.55 \\
\hline & BP-30-25-1 & $5.7(\mathrm{R})$ & $0.50 / 0.15 / 0.25 / 0.16 / 0.26$ & $30.9 / 405.0$ & 794.0 & 435.1 & 1.82 & $0.14 / 0.50$ & 655.3 & 513.8 & 513.8 & 1.55 \\
\hline & BP-30-25-2 & $5.7(\mathrm{R})$ & $0.50 / 0.15 / 0.25 / 0.16 / 0.25$ & $26.3 / 405.0$ & 725.0 & 426.6 & 1.70 & $0.14 / 0.50$ & 646.8 & 470.5 & 470.5 & 1.54 \\
\hline & TDL1-1 & $2.85(\mathrm{R})$ & $0.60 / 0.15 / 0.25 / 0.22 / 0.30$ & $30.9 / 356.0$ & 392.0 & 180.0 & 2.18 & $0.21 / 0.55$ & 258.1 & 513.4 & 258.1 & 1.52 \\
\hline & TDL1-2 & $2.85(\mathrm{R})$ & $0.60 / 0.15 / 0.25 / 0.22 / 0.30$ & $28.2 / 356.0$ & 392.0 & 180.0 & 2.18 & $0.21 / 0.55$ & 258.1 & 490.5 & 258.1 & 1.52 \\
\hline & TDL2-1 & $4.28(\mathrm{R})$ & $0.60 / 0.15 / 0.25 / 0.22 / 0.30$ & $28.6 / 356.0$ & 519.0 & 270.1 & 1.92 & $0.21 / 0.55$ & 387.3 & 494.0 & 387.3 & 1.34 \\
\hline & TDL2-2 & $4.28(\mathrm{R})$ & $0.60 / 0.15 / 0.25 / 0.22 / 0.30$ & $28.8 / 356.0$ & 472.0 & 270.1 & 1.75 & $0.21 / 0.55$ & 387.3 & 495.7 & 387.3 & 1.22 \\
\hline & TDL3-1 & $5.7(\mathrm{R})$ & $0.60 / 0.15 / 0.25 / 0.22 / 0.30$ & $29.6 / 356.0$ & 608.0 & 359.8 & 1.69 & $0.21 / 0.55$ & 515.7 & 502.5 & 502.5 & 1.21 \\
\hline & TDL3-2 & $5.7(\mathrm{R})$ & $0.60 / 0.15 / 0.25 / 0.22 / 0.30$ & $29.3 / 356.0$ & 627.0 & 359.8 & 1.74 & $0.21 / 0.55$ & 515.7 & 500.0 & 500.0 & 1.25 \\
\hline & TDS1-1 & $4.28(\mathrm{R})$ & $0.45 / 0.15 / 0.25 / 0.13 / 0.30$ & $25.6 / 356.0$ & 921.0 & 385.8 & 2.39 & $0.10 / 0.63$ & 552.8 & 791.7 & 552.8 & 1.67 \\
\hline$\stackrel{\infty}{\mathscr{\infty}}$ & TDS1-2 & $4.28(\mathrm{R})$ & $0.45 / 0.15 / 0.25 / 0.13 / 0.30$ & $27.0 / 356.0$ & 833.0 & 385.8 & 2.16 & $0.10 / 0.63$ & 552.8 & 813.1 & 552.8 & 1.51 \\
\hline$\stackrel{\Xi}{\Xi}$ & TDS2-1 & $5.7(\mathrm{R})$ & $0.45 / 0.15 / 0.25 / 0.13 / 0.30$ & $27.2 / 356.0$ & 1005.0 & 513.8 & 1.96 & $0.10 / 0.63$ & 736.2 & 816.1 & 736.2 & 1.37 \\
\hline$\ddot{\sim}$ & TDS2-2 & $5.7(\mathrm{R})$ & $0.45 / 0.15 / 0.25 / 0.13 / 0.30$ & $27.3 / 356.0$ & 1054.0 & 513.8 & 2.05 & $0.10 / 0.63$ & 736.2 & 817.6 & 736.2 & 1.43 \\
\hline 言 & TDS3-1 & $7.84(\mathrm{R})$ & $0.45 / 0.15 / 0.25 / 0.13 / 0.30$ & $28.0 / 356.0$ & 1299.0 & 706.8 & 1.84 & $0.10 / 0.63$ & 1012.6 & 916.3 & 916.3 & 1.42 \\
\hline & TDS3-2 & $7.84(\mathrm{R})$ & $0.45 / 0.15 / 0.25 / 0.13 / 0.30$ & $28.1 / 356.0$ & 1303.0 & 706.8 & 1.84 & $0.10 / 0.63$ & 1012.6 & 917.4 & 917.4 & 1.42 \\
\hline & TDM1-1 & $2.85(\mathrm{R})$ & $0.50 / 0.15 / 0.25 / 0.16 / 0.25$ & $27.5 / 383.0$ & 490.0 & 201.6 & 2.43 & $0.14 / 0.60$ & 305.6 & 520.0 & 305.6 & 1.60 \\
\hline & TDM1-2 & $2.85(\mathrm{R})$ & $0.50 / 0.15 / 0.25 / 0.16 / 0.25$ & $26.3 / 383.0$ & 461.0 & 201.6 & 2.29 & $0.14 / 0.60$ & 305.6 & 508.5 & 305.6 & 1.51 \\
\hline & TDM2-1 & $4.28(\mathrm{R})$ & $0.50 / 0.15 / 0.25 / 0.16 / 0.25$ & $29.6 / 383.0$ & 657.0 & 302.7 & 2.17 & $0.14 / 0.60$ & 459.0 & 539.5 & 459.0 & 1.43 \\
\hline & TDM2-2 & $4.28(\mathrm{R})$ & $0.50 / 0.15 / 0.25 / 0.16 / 0.25$ & $27.6 / 383.0$ & 657.0 & 302.7 & 2.17 & $0.14 / 0.60$ & 459.0 & 521.0 & 459.0 & 1.43 \\
\hline & TDM3-1 & $12.7(\mathrm{R})$ & $0.50 / 0.15 / 0.25 / 0.16 / 0.25$ & $27.0 / 370.0$ & 1245.0 & 867.7 & 1.43 & $0.14 / 0.60$ & 1315.7 & 682.6 & 682.6 & 1.82 \\
\hline & TDM3-2 & $12.7(\mathrm{R})$ & $0.50 / 0.15 / 0.25 / 0.16 / 0.25$ & $28.0 / 370.0$ & 1210.0 & 867.7 & 1.39 & $0.14 / 0.60$ & 1315.7 & 690.9 & 690.9 & 1.75 \\
\hline & BDA-30-20-70-1 & $4.25(\mathrm{R})$ & $0.45 / 0.15 / 0.20 / 0.16 / 0.25$ & $25.2 / 358.0$ & 534.0 & 303.8 & 1.76 & $0.13 / 0.45$ & 430.8 & 421.9 & 421.9 & 1.27 \\
\hline & BDA-30-20-70-2 & $4.25(\mathrm{R})$ & $0.45 / 0.15 / 0.20 / 0.16 / 0.25$ & $24.6 / 358.0$ & 549.0 & 303.8 & 1.81 & $0.13 / 0.45$ & 430.8 & 416.8 & 416.8 & 1.32 \\
\hline & BDA-30-20-80-1 & $4.25(\mathrm{R})$ & $0.45 / 0.15 / 0.20 / 0.16 / 0.25$ & $25.2 / 358.0$ & 568.0 & 303.8 & 1.87 & $0.13 / 0.55$ & 430.8 & 467.7 & 430.8 & 1.32 \\
\hline & BDA-30-20-80-2 & $4.25(\mathrm{R})$ & $0.45 / 0.15 / 0.20 / 0.16 / 0.25$ & $26.6 / 358.0$ & 564.0 & 303.8 & 1.86 & $0.13 / 0.55$ & 430.8 & 480.5 & 430.8 & 1.31 \\
\hline & BDA-30-20-90-1 & $4.25(\mathrm{R})$ & $0.45 / 0.15 / 0.20 / 0.16 / 0.25$ & $26.0 / 358.0$ & 586.0 & 303.8 & 1.93 & $0.13 / 0.65$ & 430.8 & 521.6 & 430.8 & 1.36 \\
\hline & BDA-30-20-90-2 & $4.25(\mathrm{R})$ & $0.45 / 0.15 / 0.20 / 0.16 / 0.25$ & $26.1 / 358.0$ & 588.0 & 303.8 & 1.94 & $0.13 / 0.65$ & 430.8 & 522.6 & 430.8 & 1.36 \\
\hline & BDA-30-25-70-1 & $4.25(\mathrm{R})$ & $0.45 / 0.15 / 0.25 / 0.13 / 0.25$ & $28.8 / 383.0$ & 662.0 & 343.5 & 1.93 & $0.10 / 0.43$ & 521.6 & 559.5 & 521.6 & 1.27 \\
\hline & BDA-30-25-70-2 & $4.25(\mathrm{R})$ & $0.45 / 0.15 / 0.25 / 0.13 / 0.25$ & $26.5 / 383.0$ & 676.0 & 343.5 & 1.97 & $0.10 / 0.43$ & 521.6 & 536.7 & 521.6 & 1.30 \\
\hline & BDA-30-25-80-1 & $4.25(\mathrm{R})$ & $0.45 / 0.15 / 0.25 / 0.13 / 0.25$ & $29.4 / 383.0$ & 696.0 & 343.5 & 2.03 & $0.10 / 0.53$ & 521.6 & 614.7 & 521.6 & 1.33 \\
\hline & BDA-30-25-80-2 & $4.25(\mathrm{R})$ & $0.45 / 0.15 / 0.25 / 0.13 / 0.25$ & $27.8 / 383.0$ & 725.0 & 343.5 & 2.11 & $0.10 / 0.53$ & 521.6 & 597.8 & 521.6 & 1.39 \\
\hline$\underset{\Xi}{\Xi}$ & BDA-30-25-90-1 & $4.25(\mathrm{R})$ & $0.45 / 0.15 / 0.25 / 0.13 / 0.25$ & $29.0 / 383.0$ & 764.0 & 343.5 & 2.22 & $0.10 / 0.63$ & 521.6 & 659.7 & 521.6 & 1.46 \\
\hline ¿े & BDA-30-25-90-2 & $4.25(\mathrm{R})$ & $0.45 / 0.15 / 0.25 / 0.13 / 0.25$ & $26.8 / 383.0$ & 764.0 & 343.5 & 2.22 & $0.10 / 0.63$ & 521.6 & 634.2 & 521.6 & 1.46 \\
\hline$\ddot{0}$ & BDA-30-30-70-1 & $4.25(\mathrm{R})$ & $0.45 / 0.15 / 0.30 / 0.11 / 0.25$ & $26.8 / 383.0$ & 769.0 & 364.2 & 2.11 & $0.07 / 0.41$ & 600.6 & 737.4 & 600.6 & 1.28 \\
\hline$\stackrel{\overrightarrow{7}}{\vec{n}}$ & BDA-30-30-70-2 & $4.25(\mathrm{R})$ & $0.45 / 0.15 / 0.30 / 0.11 / 0.25$ & $25.9 / 358.0$ & 730.0 & 340.5 & 2.14 & $0.07 / 0.41$ & 561.4 & 724.9 & 561.4 & 1.30 \\
\hline & BDA-30-30-80-1 & $4.25(\mathrm{R})$ & $0.45 / 0.15 / 0.30 / 0.11 / 0.25$ & $27.4 / 358.0$ & 828.0 & 340.5 & 2.43 & $0.07 / 0.51$ & 561.4 & 793.4 & 561.4 & 1.47 \\
\hline & BDA-30-30-80-2 & $4.25(\mathrm{R})$ & $0.45 / 0.15 / 0.30 / 0.11 / 0.25$ & $27.4 / 358.0$ & 809.0 & 340.5 & 2.38 & $0.07 / 0.51$ & 561.4 & 793.4 & 561.4 & 1.44 \\
\hline & BDA-30-30-90-1 & $4.25(\mathrm{R})$ & $0.45 / 0.15 / 0.30 / 0.11 / 0.25$ & $27.2 / 358.0$ & 843.0 & 340.5 & 2.48 & $0.07 / 0.61$ & 561.4 & 838.1 & 561.4 & 1.50 \\
\hline & BDA-30-30-90-2 & $4.25(\mathrm{R})$ & $0.45 / 0.15 / 0.30 / 0.11 / 0.25$ & $24.5 / 358.0$ & 813.0 & 340.5 & 2.39 & $0.07 / 0.61$ & 561.4 & 795.4 & 561.4 & 1.45 \\
\hline & BDA-40-25-70-1 & $5.67(\mathrm{R})$ & $0.45 / 0.15 / 0.25 / 0.13 / 0.35$ & $25.9 / 358.0$ & 1019.0 & 599.7 & 1.70 & $0.10 / 0.43$ & 859.2 & 871.1 & 859.2 & 1.19 \\
\hline & BDA-40-25-70-2 & $5.67(\mathrm{R})$ & $0.45 / 0.15 / 0.25 / 0.13 / 0.35$ & $24.8 / 358.0$ & 1068.0 & 599.7 & 1.78 & $0.10 / 0.43$ & 859.2 & 852.4 & 852.4 & 1.25 \\
\hline & BDA-40-25-80-1 & $5.67(\mathrm{R})$ & $0.45 / 0.15 / 0.25 / 0.13 / 0.35$ & $26.5 / 358.0$ & 1117.0 & 599.7 & 1.86 & $0.10 / 0.53$ & 859.2 & 939.8 & 859.2 & 1.30 \\
\hline & BDA-40-25-80-2 & $5.67(\mathrm{R})$ & $0.45 / 0.15 / 0.25 / 0.13 / 0.35$ & $25.5 / 358.0$ & 1117.0 & 599.7 & 1.86 & $0.10 / 0.53$ & 859.2 & 921.9 & 859.2 & 1.30 \\
\hline & BDA-40-25-90-1 & $5.67(\mathrm{R})$ & $0.45 / 0.15 / 0.25 / 0.13 / 0.35$ & $25.7 / 358.0$ & 1176.0 & 599.7 & 1.96 & $0.10 / 0.63$ & 859.2 & 983.3 & 859.2 & 1.37 \\
\hline & BDA-40-25-90-2 & $5.67(\mathrm{R})$ & $0.45 / 0.15 / 0.25 / 0.13 / 0.35$ & $26.0 / 358.0$ & 1181.0 & 599.7 & 1.97 & $0.10 / 0.63$ & 859.2 & 989.1 & 859.2 & 1.37 \\
\hline$\pi$ & BPL-35-30-1 & $6.42(\mathrm{R})$ & $0.50 / 0.15 / 0.30 / 0.14 / 0.29$ & $24.1 / 353.0$ & 960.0 & 510.9 & 1.88 & $0.11 / 0.48$ & 786.7 & 691.1 & 691.1 & 1.39 \\
\hline
\end{tabular}




\begin{tabular}{|c|c|c|c|c|c|c|c|c|c|c|c|}
\hline BPL-35-30-2 & $6.42(\mathrm{R})$ & $0.50 / 0.15 / 0.30 / 0.14 / 0.29$ & $25.6 / 353.0$ & 941.0 & 510.9 & 1.84 & $0.11 / 0.48$ & 786.7 & 705.2 & 705.2 & 1.33 \\
\hline BPB-35-30-1 & $6.42(\mathrm{R})$ & $0.50 / 0.15 / 0.30 / 0.14 / 0.29$ & $23.7 / 353.0$ & 1029.0 & 510.9 & 2.01 & $0.11 / 0.48$ & 786.7 & 687.3 & 687.3 & 1.50 \\
\hline BPB-35-30-2 & $6.42(\mathrm{R})$ & $0.50 / 0.15 / 0.30 / 0.14 / 0.29$ & $23.5 / 353.0$ & 1103.0 & 510.9 & 2.16 & $0.11 / 0.48$ & 786.7 & 685.4 & 685.4 & 1.61 \\
\hline BPH-35-30-1 & $6.42(\mathrm{R})$ & $0.50 / 0.15 / 0.30 / 0.14 / 0.29$ & $31.5 / 353.0$ & 980.0 & 510.9 & 1.92 & $0.11 / 0.48$ & 786.7 & 758.8 & 758.8 & 1.29 \\
\hline BPH-35-30-2 & $6.42(\mathrm{R})$ & $0.50 / 0.15 / 0.30 / 0.14 / 0.29$ & $32.7 / 353.0$ & 1088.0 & 510.9 & 2.13 & $0.11 / 0.48$ & 786.7 & 773.1 & 773.1 & 1.41 \\
\hline BPL-35-25-1 & $6.42(\mathrm{R})$ & $0.50 / 0.15 / 0.25 / 0.16 / 0.29$ & $27.1 / 353.0$ & 902.0 & 485.4 & 1.86 & $0.14 / 0.50$ & 702.3 & 584.3 & 584.3 & 1.54 \\
\hline BPL-35-25-2 & $6.42(\mathrm{R})$ & $0.50 / 0.15 / 0.25 / 0.16 / 0.29$ & $25.6 / 353.0$ & 872.0 & 485.4 & 1.80 & $0.14 / 0.50$ & 702.3 & 573.3 & 573.3 & 1.52 \\
\hline BPB-35-25-1 & $6.42(\mathrm{R})$ & $0.50 / 0.15 / 0.25 / 0.16 / 0.29$ & $23.2 / 353.0$ & 911.0 & 485.4 & 1.88 & $0.14 / 0.50$ & 702.3 & 554.8 & 554.8 & 1.64 \\
\hline BPB-35-25-2 & $6.42(\mathrm{R})$ & $0.50 / 0.15 / 0.25 / 0.16 / 0.29$ & $23.7 / 353.0$ & 921.0 & 485.4 & 1.90 & $0.14 / 0.50$ & 702.3 & 558.8 & 558.8 & 1.65 \\
\hline BPH-35-25-1 & $6.42(\mathrm{R})$ & $0.50 / 0.15 / 0.25 / 0.16 / 0.29$ & $36.6 / 353.0$ & 882.0 & 485.4 & 1.82 & $0.14 / 0.50$ & 702.3 & 665.0 & 665.0 & 1.33 \\
\hline BPH-35-25-2 & $6.42(\mathrm{R})$ & $0.50 / 0.15 / 0.25 / 0.16 / 0.29$ & $37.9 / 353.0$ & 951.0 & 485.4 & 1.96 & $0.14 / 0.50$ & 702.3 & 676.7 & 676.7 & 1.41 \\
\hline BPL-35-20-1 & $6.42(\mathrm{R})$ & $0.50 / 0.15 / 0.20 / 0.19 / 0.29$ & $22.5 / 353.0$ & 755.0 & 462.4 & 1.63 & $0.17 / 0.52$ & 634.3 & 472.2 & 472.2 & 1.60 \\
\hline BPL-35-20-2 & $6.42(\mathrm{R})$ & $0.50 / 0.15 / 0.20 / 0.19 / 0.29$ & $21.5 / 353.0$ & 735.0 & 462.4 & 1.59 & $0.17 / 0.52$ & 634.3 & 465.1 & 465.1 & 1.58 \\
\hline BPB-35-20-1 & $6.42(\mathrm{R})$ & $0.50 / 0.15 / 0.20 / 0.19 / 0.29$ & $20.4 / 353.0$ & 755.0 & 462.4 & 1.63 & $0.17 / 0.52$ & 634.3 & 457.0 & 457.0 & 1.65 \\
\hline BPB-35-20-2 & $6.42(\mathrm{R})$ & $0.50 / 0.15 / 0.20 / 0.19 / 0.29$ & $20.2 / 353.0$ & 804.0 & 462.4 & 1.74 & $0.17 / 0.52$ & 634.3 & 455.5 & 455.5 & 1.77 \\
\hline BPH-35-20-1 & $6.42(\mathrm{R})$ & $0.50 / 0.15 / 0.20 / 0.19 / 0.29$ & $31.4 / 353.0$ & 813.0 & 462.4 & 1.76 & $0.17 / 0.52$ & 634.3 & 529.6 & 529.6 & 1.54 \\
\hline BPH-35-20-2 & $6.42(\mathrm{R})$ & $0.50 / 0.15 / 0.20 / 0.19 / 0.29$ & $30.8 / 353.0$ & 794.0 & 462.4 & 1.72 & $0.17 / 0.52$ & 634.3 & 524.5 & 524.5 & 1.51 \\
\hline
\end{tabular}

As: reinforcement considered for STM or punching calculations (per side or direction) - (B): bunched; (D): diagonals; (R): rectangular mesh

e: pile spacing between axis; $\phi$ : pile diameter/side; c: column diameter/side; v: shear span; d: effective depth;

$\mathrm{f}_{\mathrm{c}}$ : cylinder compressive strength of concrete; $\mathrm{f}_{\mathrm{y}}$ : yield strength of reinforcing steel in tension; $\mathrm{P}_{\mathrm{u}, \mathrm{e}}$ : ultimate experimental load;

$\mathrm{P}_{\mathrm{u}, \mathrm{STM}(\chi \mathrm{d})}$ : ultimate load predicted by the reference STM; $\mathrm{a}_{\mathrm{v}}$ : distance between column and pile edges; u: basic control perimeter; $\mathrm{P}_{\mathrm{u}, \mathrm{STM}\left(\chi_{\mathrm{u}}, \mathrm{Otsuki}\right)}$ : ultimate load predicted by Otsuki [26]

$\mathrm{P}_{\mathrm{u}, \mathrm{V} \text { red }}:$ Reduced ultimate punching load based on Eurocode $2[16] ; \mathrm{P}_{\mathrm{u}, \mathrm{SV}}$ : Ultimate load proposed by authors 
(a)

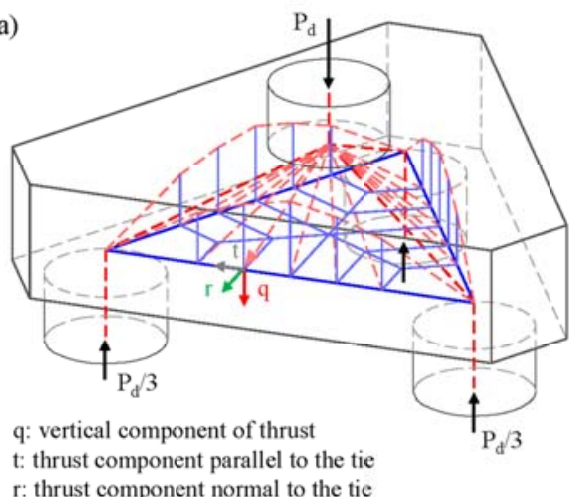

(b)

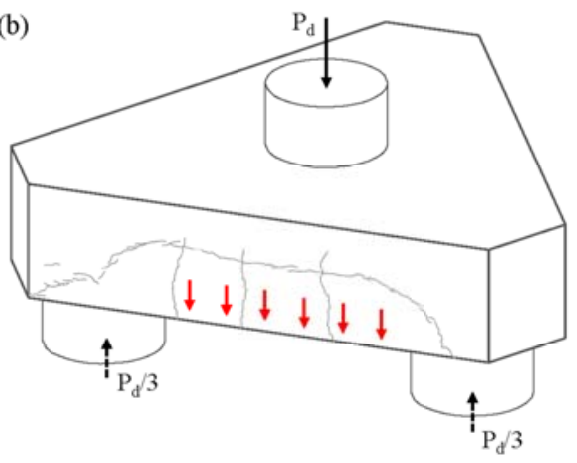

Fig. 1 Distribution of the column load between piles and edges: (a) Components of the thrust effect on sides; (b) Cracking pattern on 3P-N-A1 showing the side thrust effect

(a) Type 1: $A_{\mathrm{sB}}$

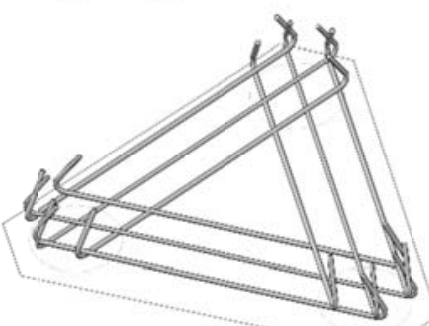

(b) Type 2: $A_{s 13}+A_{s 11}$

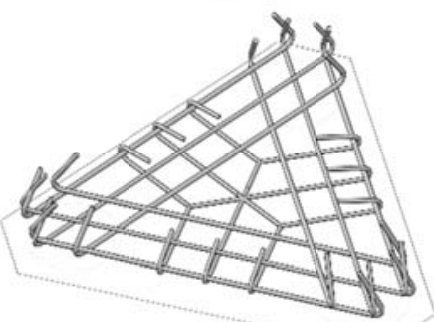

(c) Type 3: $A_{s B}+A_{s 11}+A_{s V}$

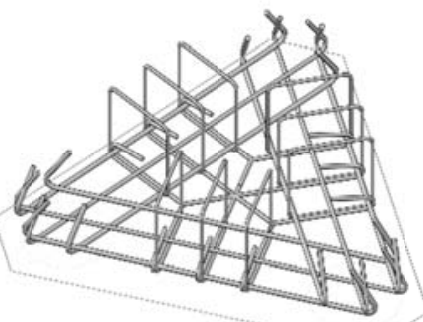

Fig. 2 Reinforcement layout: (a) Type 1; (b) Type 2; (c) Type 3 
(a)

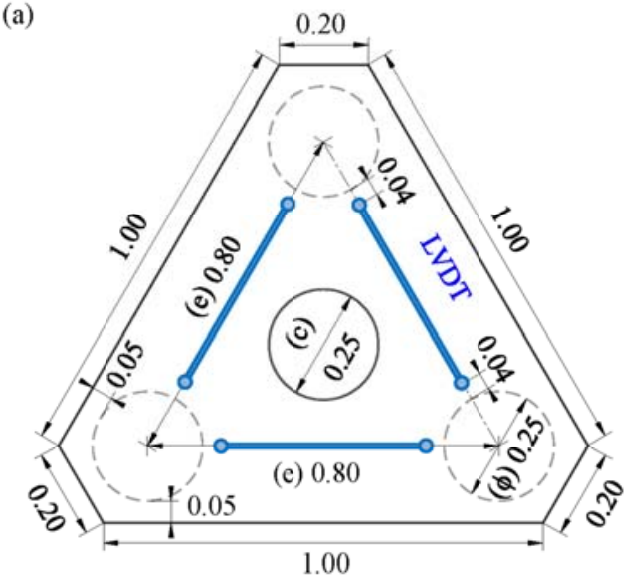

(b)

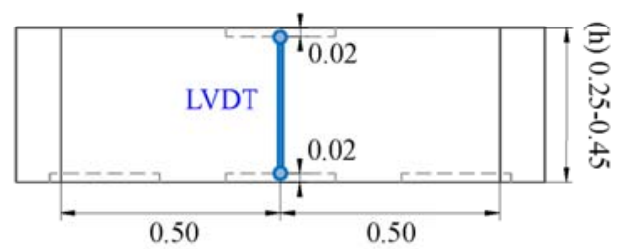

536 Fig. 3 Main dimensions and LVDT location: (a) Plan view; (b) Elevation

(a)

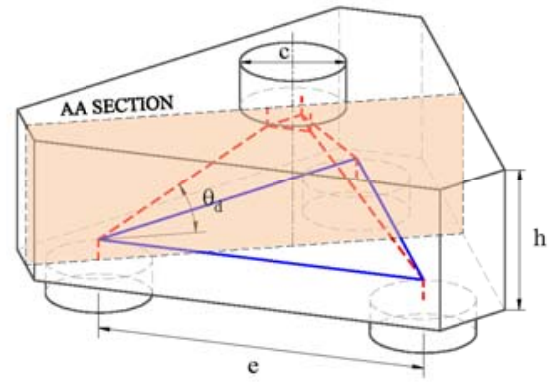

(b)

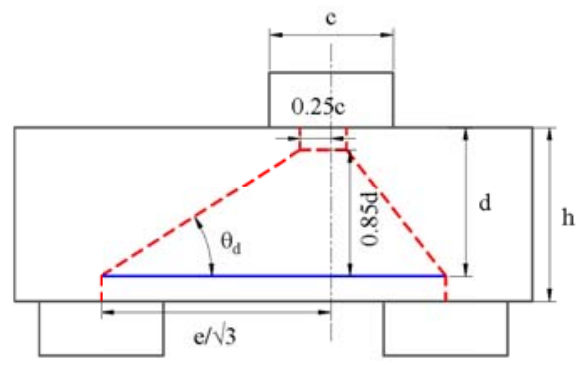

(c)

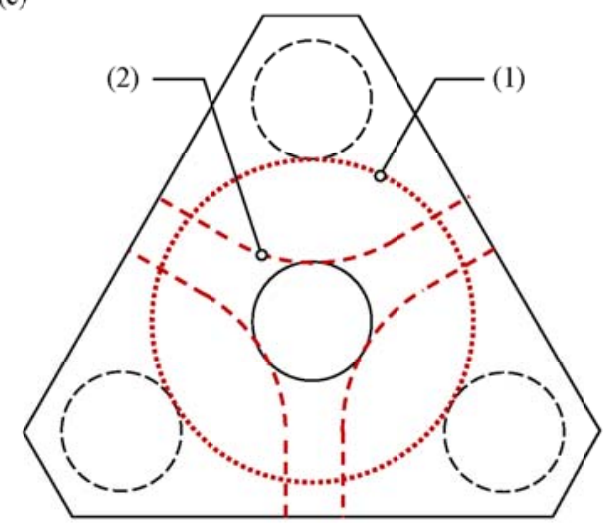

Fig. 4 (a) A three-dimensional strut-and-tie model for three-pile caps; (b) AA Section of STM; (c) Basic control perimeters: (1) Punching of column, (2) Punching of pile cap 

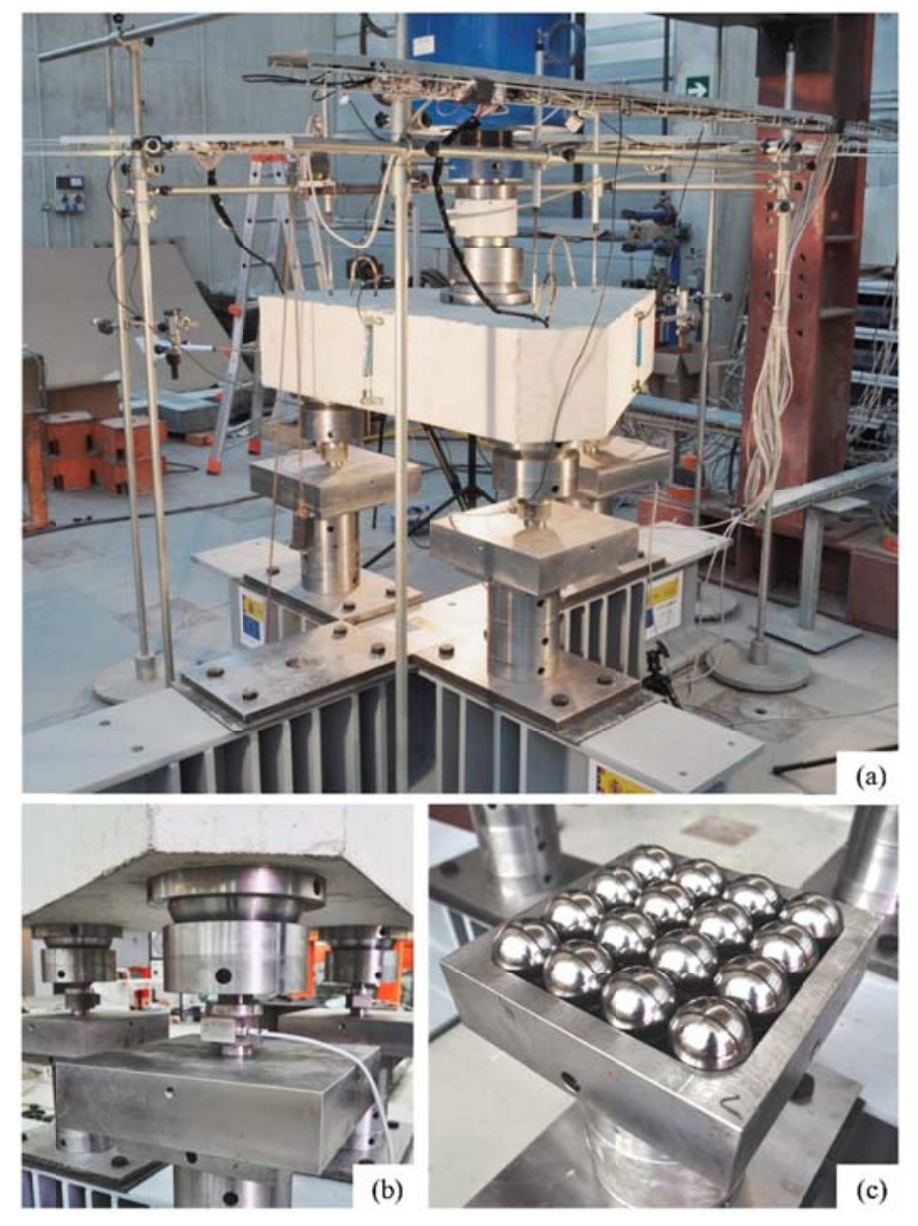

541 Fig. 5 Test setup: (a) General view; (b) Hinge under supports; (c) Ball bearings

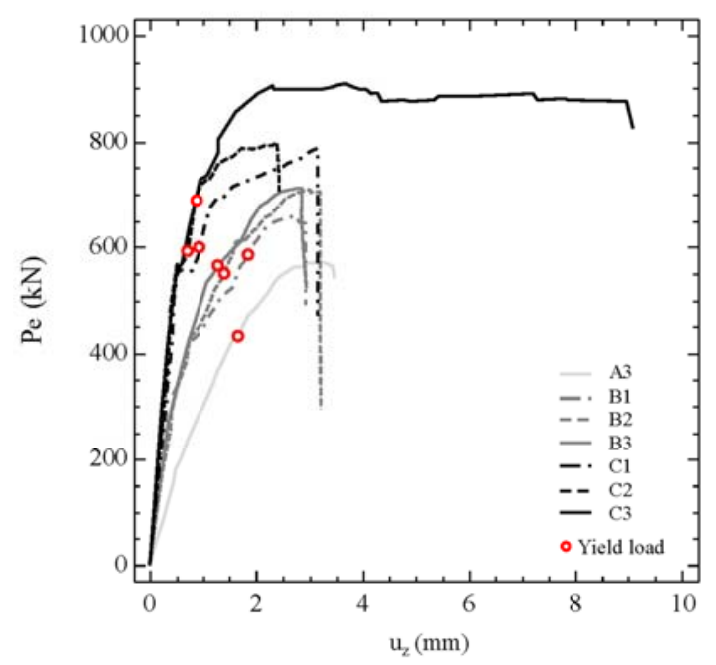

543 Fig. 6 Load-displacement curves 


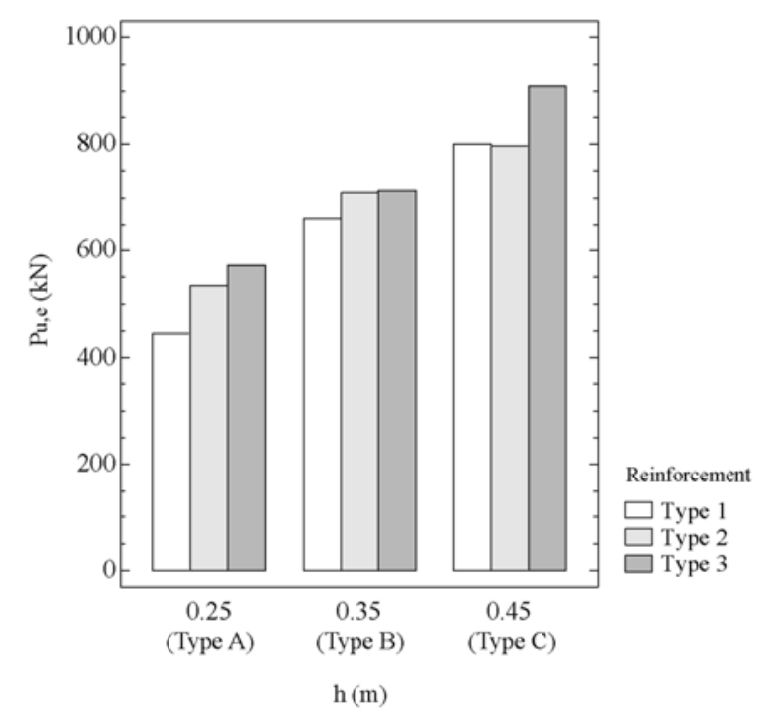

545 Fig. 7 Effect of the depth (types A,B and C) and reinforcement arrangement (types 1, 2 and 3) on failure load

(a)

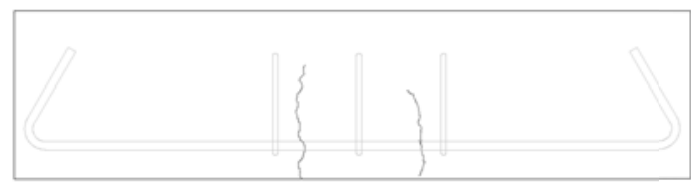

(b)

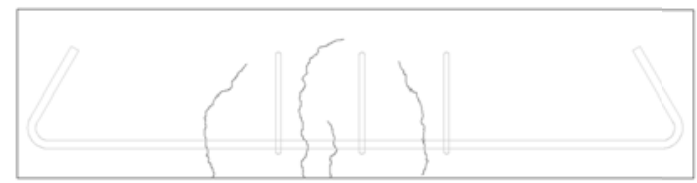

(c)

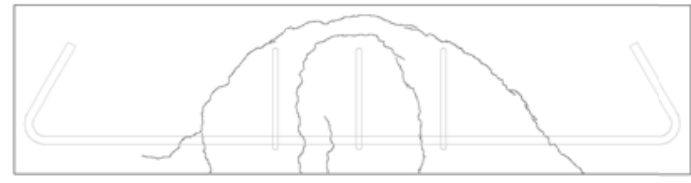

(d)

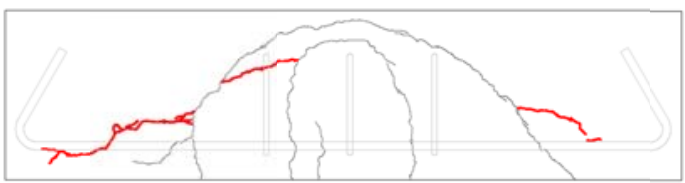

547 Fig. 8 Crack development stages for 3P-N-A3: (a) Early bending cracks - 350kN; (b) Threshold of yielding $548 \quad 432.8 \mathrm{kN}$; (c) Arched cracks at peak load $-573.2 \mathrm{kN}$; (d) Tail of shear cracks after failure 

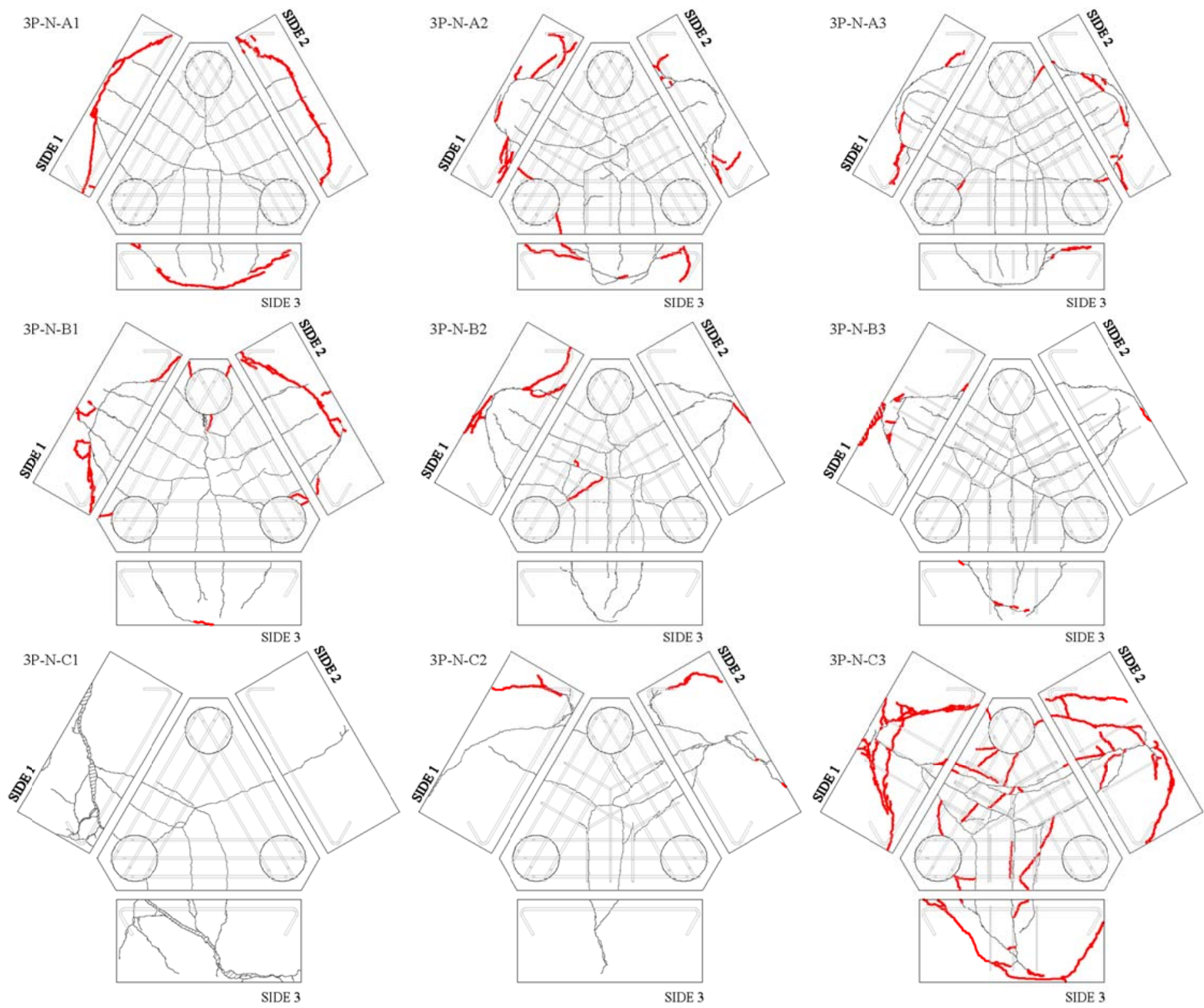

CRACKING LEGEND

- At peak load

550 Fig. 9 Crack pattern after peak load 
a) ข 3P-N-B1

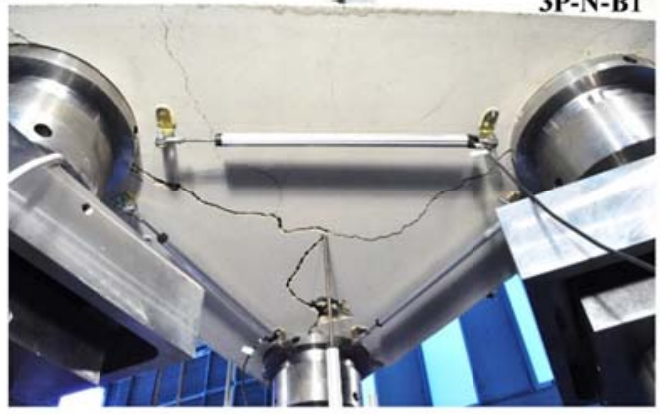

b)

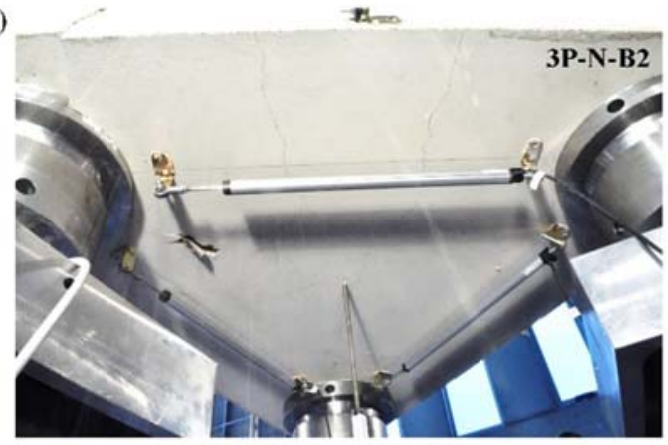

552 Fig. 10 Effect of horizontal secondary reinforcement on the crack width control upon peak load: (a) 3P-N-B1; (b) 553 3P-N-B2
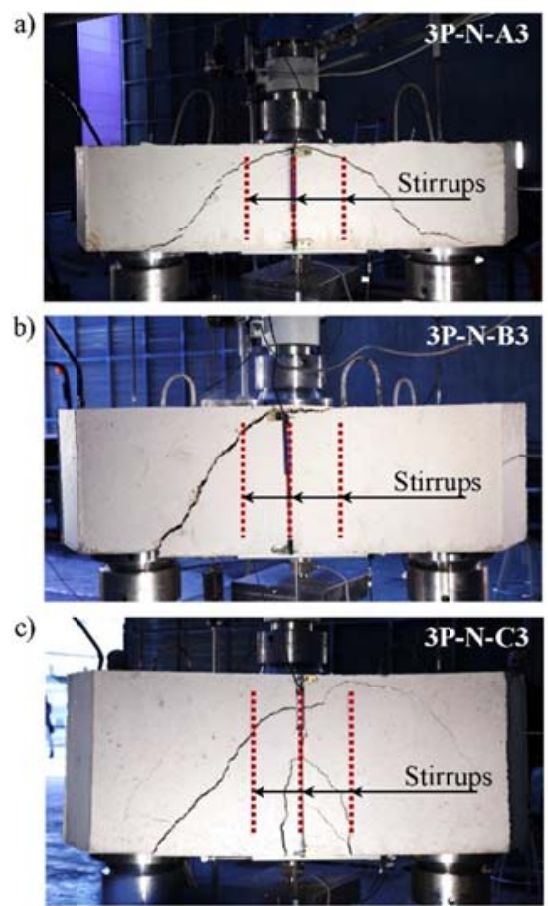

557 Fig. 11 Specimens with vertical stirrups upon peak load: (a) 3P-N-A3; (b) 3P-N-B3; (c) 3P-N-C3 
(a)

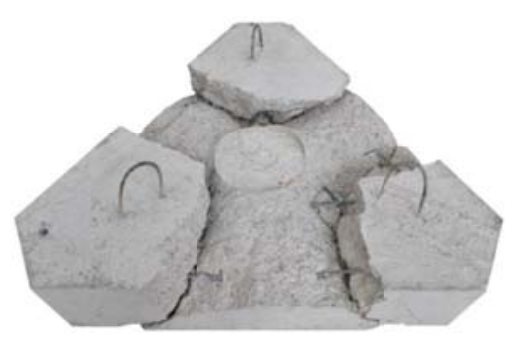

(b)

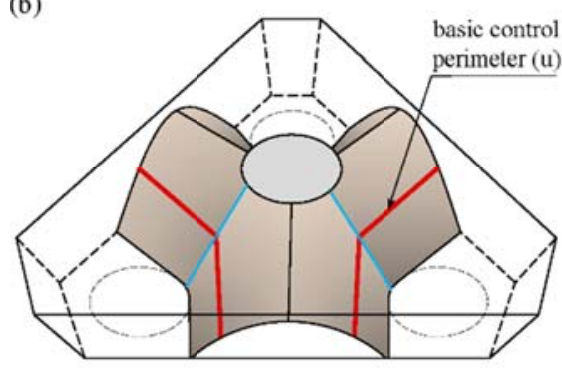

(c)
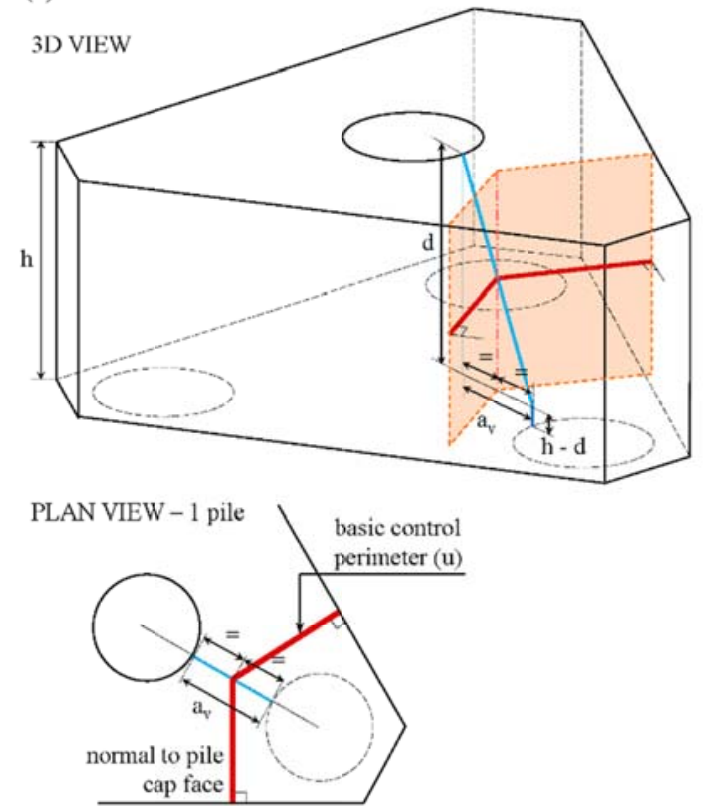

558

Fig. 12 Punching failure surface: (a) 3P-N-A3; (b) Failure surface proposal; (c) The basic control perimeter proposal

(a.1)

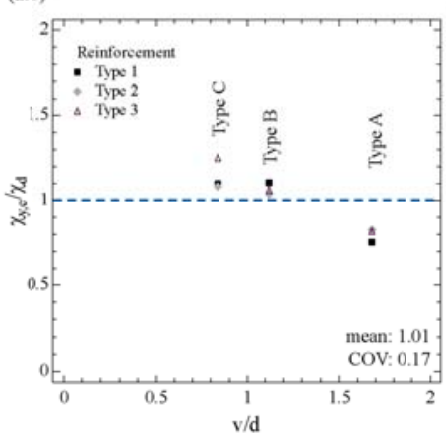

(c.l)

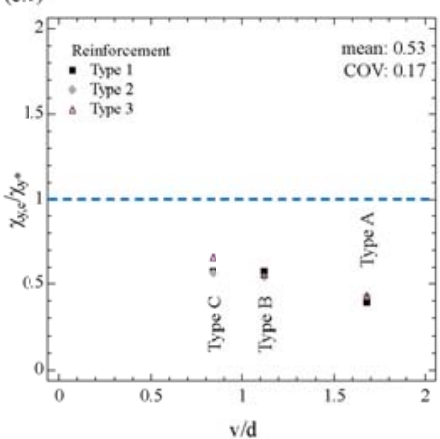

(a.2)

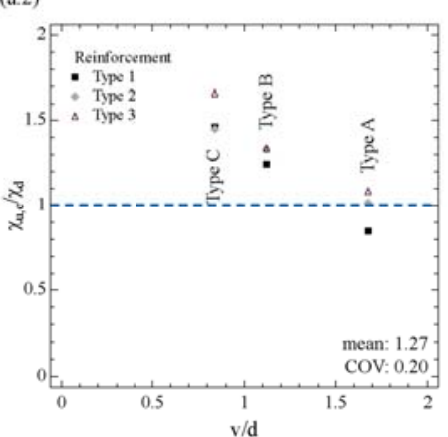

(e.2)

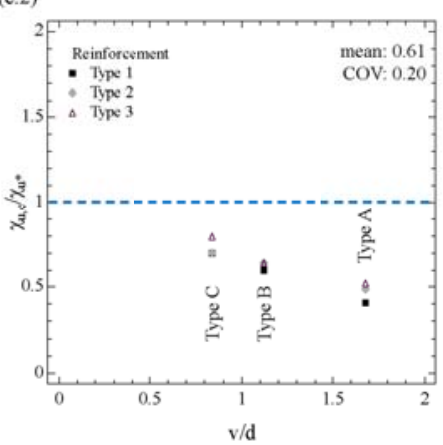

(b)

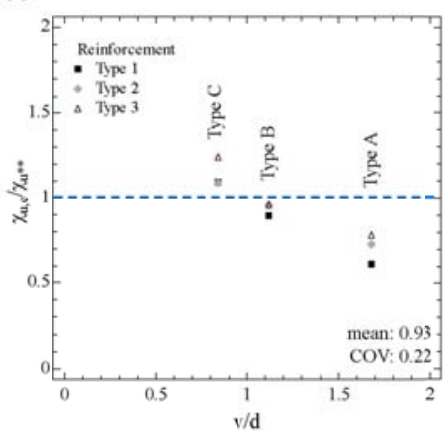

(c.3)

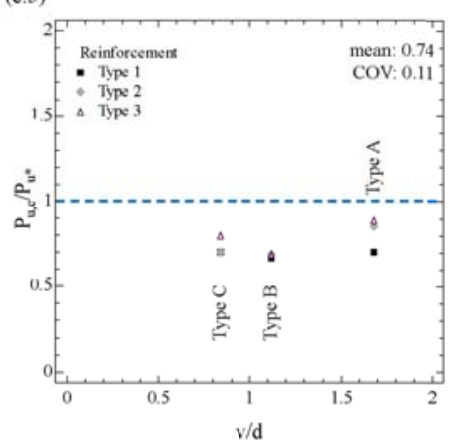

Fig. 13 Comparison between experimental results and theoretical models: (a) Reference STM: (a.1) Yield load; 


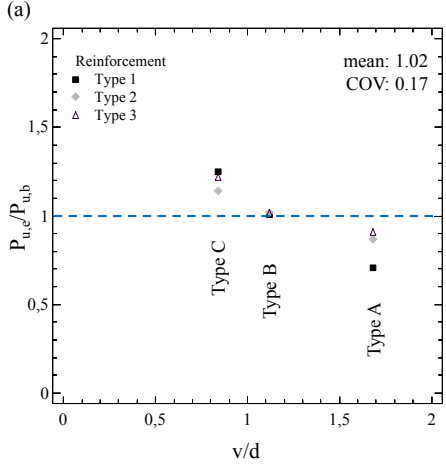

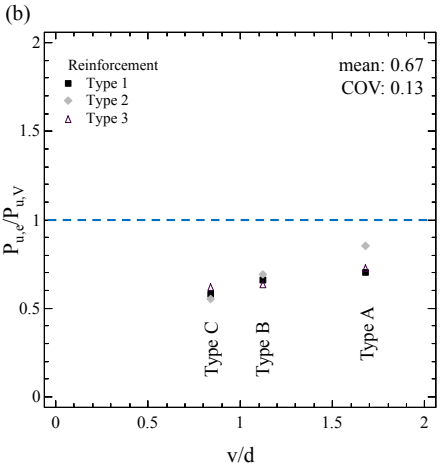

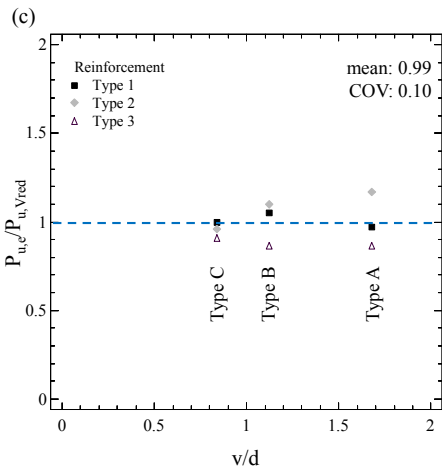

Fig. 14 Fragile failure limitations: (a) Bearing stress according to Eurodode 2 [16]; (b) Punching according to Eurodode 2 [16] when applying the enhancement factor to the whole basic control perimeter "u"; (c) Proposed punching formulation: punching according to Eurodode 2 [16] when applying the enhancement factor only to the " $\mathrm{u}_{\mathrm{eff}}$ " perimeter

(a)

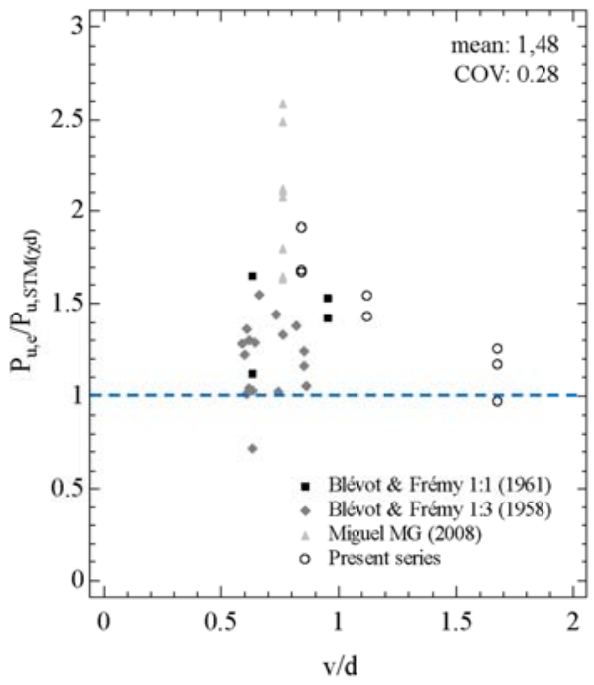

(b)

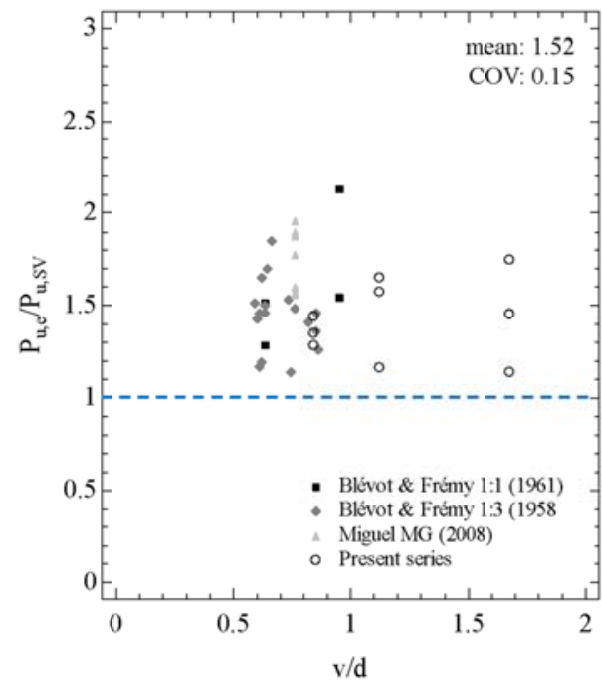

573 Fig. 15 Peak load predictions: a) STM design; b) The proposed formulation for three-pile caps 
(a)

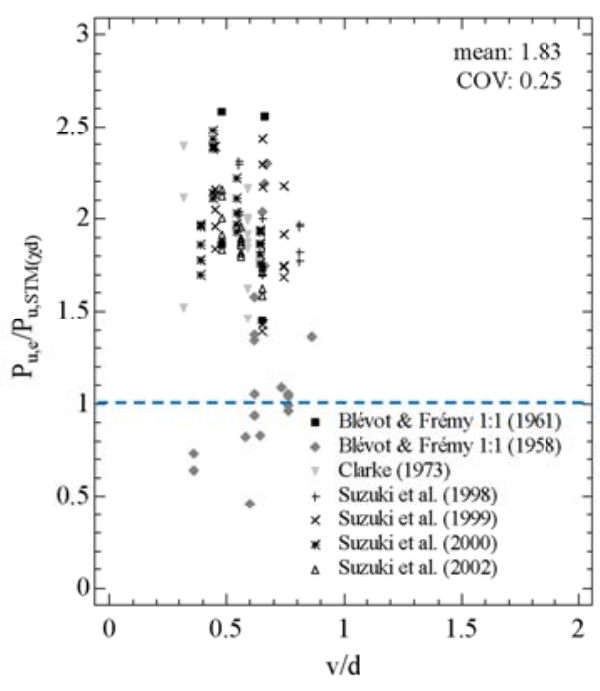

(b)

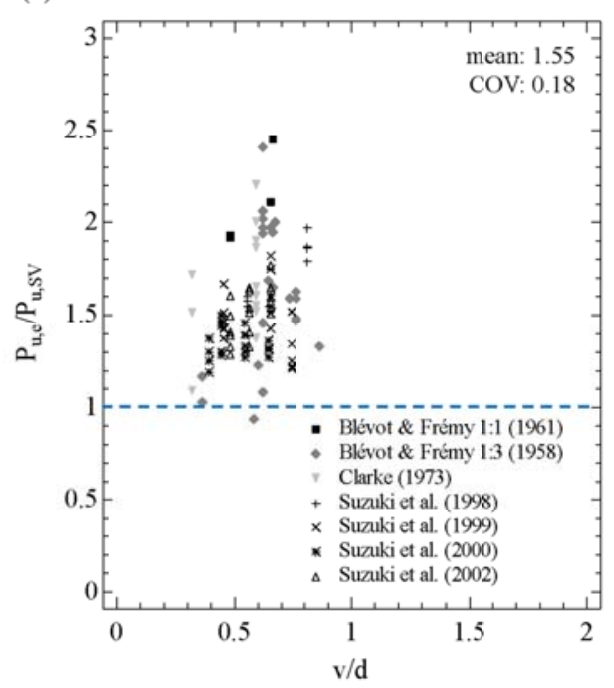

575 Fig. 16 Peak load predictions: a) STM design; b) The proposed formulation for four-pile caps 